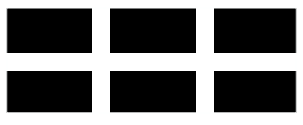

ThE WILliAM DAVIDSON INSTITUTE AT THE UNIVERSITY OF MICHIGAN BUSINESS SCHOOL

\title{
Contract Violations, Neighborhood Effects, And Wage Arrears in Russia
}

\author{
By: John S. Earle and Klara Sabirianova Peter
}

William Davidson Institute Working Paper Number 708

July 2004 


\title{
CONTRACT VIOLATIONS, NEIGHBORHOOD EFFECTS, AND WAGE ARREARS IN RUSSIA*
}

\author{
John S. Earle \\ Upjohn Institute for Employment Research \\ Central European University \\ and \\ Klara Sabirianova Peter \\ University of Michigan \\ CEPR, IZA and WDI
}

July 2004

\begin{abstract}
We present a model of neighborhood effects in wage payment delays. Positive feedback arises because each employer's arrears affect the late payment costs faced by other firms in the same local labor market, resulting in a strategic complementarity in the practice. The model is estimated on panel data for workers and firms in Russia, facilitating identification through the use of a rich set of covariates and fixed effects for employees, employers, and local labor markets. We also exploit a policy intervention affecting public sector workers that provides an instrumental variable to estimate the endogenous reaction in the non-public sector. Consistently across specifications, the estimated reaction function displays strongly positive neighborhood effects, and the estimates of four feedback loops - operating through worker quits, effort, strikes, and legal penalties - imply that costs of delays are attenuated by neighborhood arrears. We also study a nonlinear case exhibiting two stable equilibria: a "punctual payment equilibrium" and a "late payment equilibrium." The estimates imply that the theoretical conditions for multiple equilibria under symmetric local labor market competition are satisfied in our data.
\end{abstract}

JEL Classifications: A12, B52, J30, K42, L14, O17, P31, P37

Keywords: wage arrears, contract violation, neighborhood effect, social interactions, multiple equilibria, network externality, strategic complementarity, transition, Russia.

*Earle: 300 S. Westnedge Ave., Kalamazoo, MI, 49007 (earle@upjohn.org). Sabirianova Peter: 724 E. University Ave, Ann Arbor, MI, 48109 (klaras@umich.edu). This paper is a thorough revision of our earlier "Equilibrium Wage Arrears." While the essential conclusions remain the same, this revision employs new data and new econometric methods for identification, and it provides more extensive empirical evidence on the model's assumptions. Our early research on the topic was supported by the European Union's Tacis ACE Programme, Ford Foundation, and MacArthur Foundation. We are also grateful to Andrzej Baniak, David Brown, Jiahua Che, Fabrizio Coricelli, Steven Durlauf, Tore Ellingsen, Bob Flanagan, Guido Friebel, John Garen, Scott Gehlbach, Vladimir Gimpelson, Rostislav Kapeliushnikov, Hartmut Lehmann, Larry Levin, Joanne Lowery, Peter Murrell, Ugo Pagano, Andrew Spicer, Bill Sundstrom, Valery Yakubovich, Yury Yegorov, and participants in conferences and seminars in Berkeley, Bonn, Budapest, Kalamazoo, Madison, Moscow, Prague, Seattle, and Stanford for helpful comments and discussions, and we thank Paul Milgrom for a conversation that encouraged us to develop the model in this paper, but reserve to ourselves the responsibility for any errors. 


\section{Introduction}

Timely payment of wage obligations is a standard feature of most employment relationships and a virtually universal and unquestioned assumption of economists studying labor markets. In developed market economies, the rule of wage payment in full and on time is proven by the rare exceptions appearing in small start-up companies facing severe liquidity constraints, in bankrupt firms about to be shut down, or in situations of fraud. The routine practice among employers of honoring their compensation promises is presumably guaranteed both by legal institutions and by self-enforcing considerations such as the firm's interest in protecting its reputation as a reliable contractor when hiring and motivating other workers (for reasons surveyed by, e.g., Malcomson, 1997).

In post-Soviet Russia and a few other formerly socialist economies, by contrast, wage delays and nonpayments have risen quickly to become large, widespread, and persistent. Although aggregate figures are incomplete, estimates from the Russian State Committee for Statistics imply that the cumulative overdue wage debt in Russia grew from a negligible level in 1991 to 77 bln rubles by the end of 1998, with 132,320 enterprises reporting arrears amounting to 374 percent of their total monthly wage bill in December of that year (Goskomstat, 1999). As we show in our empirical analysis of microdata below, approximately two-thirds of Russian workers reported overdue wages in late 1998, with an average debt of 4.8 monthly salaries per affected worker. Although declining concurrently with rapid economic growth since 1999, arrears continue to affect more than five million Russian workers according to a recent trade union report (Radio Free Europe/Radio Liberty Newsline, 2004). Not only large in magnitude, late payments have been widespread in many sectors and types of firms; indeed, the incidence and magnitude of arrears appear to be greater in large firms and state-owned organizations. ${ }^{1}$

This paper attempts to explain the puzzle of how high and persistent wage arrears in a few economies can co-exist with only negligible, transitory arrears in most others. Our empirical work focuses on Russia, both because of data availability and because the substantial variation of arrears within Russia provides a fruitful testing ground for our theory. But our theoretical model is general, applying to wage arrears determination in other transition economies as well as providing an explanation why wage arrears are such an uncommon practice in most economies.

\footnotetext{
${ }^{1}$ Gimpelson (1998), Lehmann, Wadsworth, and Acquisti (1999), Desai and Idson (2000), and Earle and Sabirianova
} (2002) describe some of the empirical patterns of Russian wage arrears. 
Our analysis begins with the observation that a combination of peculiar conditions may have tended to raise the attractiveness of wage delays in some Russian companies. The conditions include the broad decline of output and employment for many years, the associated problems with liquidity, the poor monitoring of managerial behavior, and the general lack of contract enforcement. These conditions may have increased firms' and managers' returns to delaying wages, but we argue that they alone cannot account for several pronounced empirical regularities. The puzzles include the presence of arrears even at firms showing strong growth and liquidity performance, the large geographic variation in the magnitude of overdue wages, the tendency for arrears to concentrate in the state-owned sector, the persistence of substantial delays over time, and workers' apparent tolerance of the practice for years on end.

The key argument we develop in this paper is that self-propagation of the practice of wage contract violations may arise due to neighborhood effects among employers within local labor markets. Our claim is that a decision to delay wages by one employer has externalities for other firms considering a late payment strategy, particularly for those operating in the same local labor market. The externality arises because employees of a late-paying firm are less likely to engage in several costly actions_quitting, reducing effort, or striking —in response to their own arrears when other firms in the region also pay late. Legal congestion may also contribute to a positive feedback loop, as the probability of judicial punishment may decline with the incidence of arrears in the local jurisdiction (as in Sah, 1991). In these ways, the cost to a manager of a wage delay strategy is a function of the wage delay decisions taken by other firms, and the timeliness of payment practice becomes a strategic complement for firms operating in the same labor market.

We present this argument in the form of a model of the managerial choice of wage delays, where a critical factor in the decision is the prevalence of arrears in the firm's local labor market. The model implies neighborhood effects in wage payment practices due to feedback loops from the local environment. Under some conditions, the model generates multiple equilibria in the level of wage arrears: a stable "punctual payment equilibrium," an unstable "critical mass equilibrium," and a stable "late payment equilibrium." The stable equilibria can be interpreted as reflecting institutional lock-in, in the case of the late payment equilibrium implying that massive coordination may be required to move the economy back to the institution of punctual payment. The model explains not only why arrears may tend to persist, but also 
some other empirical regularities of arrears: the strong regional variation, the presence of delays at many firms that are expanding employment and wages, the persistence of substantial arrears over several years, and the quiescent response of most workers to the practice. Although focusing attention on the effect of interaction among employers in spurring and sustaining arrears, the model includes other factors that may have affected firm and worker behavior, and thus it suggests important variables that should be controlled for in the empirical analysis.

Estimating such a model of employer interactions faces similar identification problems to those in studies of neighborhood effects and social interactions (e.g., Brock and Durlauf, 2001; Moffitt, 2001). Our identification strategy takes advantage of a policy intervention for a subsample of individuals: employees of organizations financed from the state budget. The exogenous rise of wage arrears in the public sector provides a valid instrument for an analysis of the effect of local labor market arrears on the decisions of non-public sector employers. The multi-level and panel aspects of the data allow us to control for correlated effects at the individual, firm, and local labor market levels. In addition to estimating an identified reaction function, our empirical work examines some of the assumptions of the model. Among these are the four feedback loops_-involving quits, changes in effort, strikes, and legal penalties_-that we argue may reinforce the use of a wage delay practice. We also examine the maintained hypotheses that wage rates are exogenous in the arrears equation and that public-sector arrears are exogenous to arrears behavior in the non-public sector. The final empirical analysis in the paper involves the estimation of a nonlinear form of the reaction function. As an example of a possible nonlinear form, we derive and estimate a cubic function for the neighborhood effects among employers. Assuming symmetric competition in the local labor market and Nash behavior by managers, we calculate the three equilibria implied by our empirical estimates.

The next section of the paper introduces our data. Section 3 presents a simple model of wage arrears determination to motivate our analysis of firm interactions in local labor markets and of the feedback loops that may support the use of the wage arrears practice. Section 4 describes our identification strategy and presents results for the basic linear reaction function. Section 5 contains results for the estimation of feedback loops and other model assumptions. The possibility of a nonlinear reaction function is developed theoretically and estimated empirically in Section 6. Section 7 concludes with a brief summary and discussion of some wider implications of the analysis. 


\section{Data}

\subsection{Data Sources}

Our model analyzes the choice of wage arrears in a particular employment relationship for a firm and worker. The data required to test the model include detailed information on both sides of the relationship. To meet these requirements, this paper uses several data sources. The principal source, used in most analyses below, consists of the 1994, 1995, 1996, 1998, and 2000 waves of a household panel survey, the Russian Longitudinal Monitoring Survey (RLMS), based on the first national probability sample drawn in the Russian Federation. ${ }^{2}$ The panel structure is particularly useful in permitting us to employ individual, firm, and district fixed effects in our estimating equations.

For the purpose of our analysis, we have extended the original RLMS data in a number of ways. First, we have used information provided by most working respondents on their employers (but not included in the published data set) to identify individual firms and the industries in which they operate. ${ }^{3}$ This allowed us to control for constant firm heterogeneity and time-varying industry of employment. Another important benefit of our ability to identify the specific employer for most observations was that it enabled us to construct reliable measures of job mobility. We can distinguish job quits reliably from intrafirm mobility, and we can measure job tenure accurately. These are critical variables in our theoretical model.

A second major data source is a detailed survey of agricultural and industrial employers, which collected information on wage arrears and other aspects of firms for the period 1991-99. Our sampling design attempted to interview every identifiable employer of RLMS respondents, thus constituting a national probability sample of employers in industry and agriculture, with selection probability proportional to employment size. ${ }^{4}$ Unlike most surveys of firms, our procedure did not replace nonresponding firms with other observations, and interviewers expended great efforts to include every firm on their sample lists. As a result of this procedure,

\footnotetext{
${ }^{2}$ See Swafford et al. (1997). The RLMS data contain results of two longitudinal surveys of more than 10,000 individuals during a first wave in 1992-1993 (Rounds 1-4) and a second wave in 1994, 1995, 1996, 1998, 2000, and 2001 (Rounds 5-10). No information on wage arrears is available in the first wave, and availability of firm information restricts our attention in this paper to Rounds 5-9 from the second wave.

${ }^{3}$ Some ambiguities of classification prevented us from coding industry for all jobs, but we were able to code the following number of cases: 4828 respondents of 4896 employed in 1994, 4528 of 4575 employed in 1995, 4346 of 4383 employed in 1996, 4215 of 4250 employed in 1998, and 4449 of 4508 employed in 2000.

${ }^{4}$ This statement is of course conditional on the RLMS sampling, which involves a two-stage geographic stratification procedure followed by random drawing of households (residences). Again, see Swafford et al. (1997) for details.
} 
the response rate was approximately 64 percent among industrial firms (522 firms) and 73 percent among agricultural firms (75 firms). Missing values for the wage arrears variable reduce the sample to 560 firms, of which 486 come from the industrial firm survey and 74 from the agricultural firm survey. We also have added regional data from the Russian Labor Ministry Inspection Service on the patterns of violations of the Russian Labor Code and how the cases were treated. These data are useful in constructing measures of the effectiveness of the legal enforcement regime in the region.

\subsection{Measuring Wage Arrears}

Measuring wage arrears is subject to several problems. In practice, arrears tend to accumulate irregularly, with occasional, lumpy repayments of back wages. In theory, one might like to measure the present discounted loss due to wage delays taking into account the risk premium associated with the uncertainty of the timing (and probability) of future payment. Such a measure would require detailed information on the salary history of each worker and on his/her discount rate and expectations concerning future payment.

Accounting practice in Russia—both at the individual firm level and by Goskomstatinstead focuses on the cumulative debt of the firm to its workers, without regard to the timing of the overdue payments. The stock of overdue wage debt is frequently expressed in terms of the monthly wage bills (payrolls) the firm owes. ${ }^{5}$ Workers think of the value of arrears in the same way: the number of monthly salaries that have not yet been paid. This question is asked directly on the RLMS, and this is the measure of individual wage arrears (denoted $\omega$ ) that we analyze in this paper.

As shown in Table 1, the unconditional mean of $\omega$ rose from 1994 to 1996 and again in 1998 before falling in 2000; the distribution of the variable shows pronounced rightward shifts in 1996 and 1998. The proportion of workers with two or more months of arrears was already about 25 percent in 1994, and it had increased to nearly 44 percent by 1996 and 50 percent by late 1998. Conditional on having arrears, the expected magnitude rose from 2.8 to more than 4.8 months. Clearly the overall increase in arrears reflects both a spreading of the contagion to previously unaffected workers and a worsened condition for those already affected.

In our empirical tests of the model's hypotheses, we construct a measure of local arrears $(\Omega)$ from the RLMS by aggregating $\omega$ up to the district (rayon) level, each time omitting the

\footnotetext{
${ }^{5}$ Wages are paid monthly in Russia, as in most European countries.
} 
particular firm for which the individual worker is employed. While analyses of Russian regions are frequently conducted at the level of the oblast, we feel that the district much better reflects the scope of the local labor market. ${ }^{6}$ Table 1 shows the substantial variation across districts: the cities of Moscow and St. Petersburg had trivial levels of arrears, for instance, while in some other districts average arrears reached as high as 12 monthly wages per employee.

\subsection{Sample Characteristics}

Table 2 displays means and standard deviations for worker and job characteristics in the RLMS sample. The sample is restricted to employees at their primary job. 36.7 percent are employed in the public sector, which is defined on the basis of industries paid through the state budget in Russia: defense industries, municipal utilities, health services, social work, education, culture and art, science, public administration, and public order and safety. Definitions of most individual attributes (such as gender, age, job tenure, years of schooling, employee ownership, occupation, and industry) are straightforward. The hourly wage rate is computed as the ratio of the contractual wage in the previous month to the usual hours of work in the previous month. ${ }^{7}$ Family income includes per capita income (monetary and in-kind) received during the past month from all jobs, as well as the retirement and unemployment benefits of all other members of the household. All income measures are calculated in constant December 2000 prices using the monthly Consumer Price Index (CPI).

Previous studies have found that wage arrears are more common among men, negatively associated with schooling, and positively related to age and job tenure; these may reflect considerations of skill specificities, mobility costs, and outside opportunities. ${ }^{8}$ Workers with arrears are more likely to be small shareholders and tend to have lower hourly wages and family incomes. Craft workers and operators and assemblers tend to experience the highest rates, while managers have the lowest-although the rate is high even for this occupation. Variation across

\footnotetext{
${ }^{6}$ There are 89 oblasts or "subjects" (including autonomous republics, etc.) of the Russian Federation, some of which are larger than Texas, others of which are as small as Rhode Island. The next lower administrative level is the rayon, of which there are an average of 22 per oblast, thus roughly equivalent to a county in the U.S. In our data, there are 52 rayons, thus 52 different values of $\Omega$ in each year of the RLMS sample.

${ }^{7}$ Because wage arrears introduce high volatility in the wage as measured in a given reference period, the reported wage is frequently zero (as high as 30 percent of responses by workers), and it will be lower than the contractual wage when new wage debts are incurred and higher than the contractual wage when they are paid off. To handle the problem of measuring the contractual wage, we have added an additional question to the RLMS in 1998 and 2000 to collect this information, and for the earlier years we have followed the method of Earle and Sabirianova (2002), imputing the contractual wage as the ratio of the total wage debt to the number of monthly wages owed $(\omega)$.

${ }^{8}$ Earlier versions of the paper contained information on the incidence and magnitude of arrears for each characteristic separately; these results are available on request. See also Lehmann, Wadsworth, and Acquisti (1999), Desai and Idson (2000), and Earle and Sabirianova (2002).
} 
industries is also large, with higher incidence and magnitude in agriculture, defense and heavy industrial sectors, as well as in services financed through the state budget (education and health). In a new and rapidly developing sector like banking and finance, however, arrears are very small.

Summary statistics for the firm sample are provided in Table 3. Compared with the worker reports in Tables 1 and 2, mean $\omega$ and $\Omega$ are somewhat smaller in the firm data (although variation in these two variables is quite similar across sources). There are two reasons for the difference: the time span begins earlier in the firm survey (as early as 1991 for some firms), and the firm survey excludes most of the public sector. The latter consideration prevents us from estimating an identified reaction function using the firm survey and following the estimation strategy described in Section 4; the firm survey data are therefore employed only in the estimation of some of the feedback loops associated with costs of arrears.

Table 3 also shows characteristics of the firm sample used as controls: union density, provision of fringe benefits, training costs, industry, local type, and legal environment. These variables, as well as the quit rate and the incidence of strikes and legal penalties, are introduced in the empirical sections below.

\section{A Model of Wage Arrears}

In this section, we present a highly stylized model of managerial decisions concerning wage delays. The model is designed to focus attention on the possibility of neighborhood effects in arrears through the influence of the behavior of other employers in the local labor market on the decision of a firm concerning the practice. It is also useful as a framework for considering several types of feedback loops that may support the use or nonuse of the late payment practice, for laying out critical assumptions in the analysis, and for suggesting important factors to control for in the empirical work. Although arrears decisions have an important dynamic component, including the expectations of managers and workers concerning each other's behavior and the evolution of exogenous determinants, our static model captures the essential features of arrears we would like to describe. ${ }^{9}$

The main result of the model is a general reaction function that relates an individual firm's arrears behavior to the prevalence of arrears in the firm's local labor market. This reaction function is assumed to apply only to firms in the non-public sector of the economy, as

\footnotetext{
${ }^{9}$ In addition, it is problematic to estimate a dynamic model because of the shortness and low frequency of the time series available.
} 
public sector arrears are affected by centralized decisions concerning the payments of obligations and the distribution of revenue-sharing across different levels of government. ${ }^{10}$ This assumption forms an important basis for our identification strategy in empirically estimating the linear form of the reaction function in Section 4; further discussion and evidence on the issue is provided in Section 5 .

\subsection{Returns and Costs to Wage Arrears}

Consider a non-public firm with a single manager who chooses the level of back wages owed a particular employee in a particular time period to maximize his/her private net benefits. ${ }^{11}$ This level, $\omega$, can be thought of as an involuntary loan from the worker to the firm, and we assume it earns the manager a gross per-period return of net present value $R(\omega, X)$, with marginal return $R_{\omega}(X)=r(X)$ assumed to be constant in $\omega$ but varying according to some characteristics of the firm, $X$ (defined so that $r_{x}>0$ ). The relevant characteristics may include the liquidity needs of the firm, the effective interest rate that it faces in borrowing from other sources, and the ability of the manager to appropriate the returns by diverting the funds to projects earning private benefits. In Russia until August 1998, for example, poorly monitored managers could invest spare funds in short-term government treasury bills (GKOs), earning rates up to 150 percent. In such situations, wage arrears are likely to be more attractive to managers who can relatively easily and secretly channel the extra cash flow to their own purposes.

While it is not difficult to appreciate the potential returns that might be obtained from postponing wage payments, the manager naturally faces costs of wage arrears as well. We hypothesize several types of potential costs: increased worker turnover, lowered effort, and higher probabilities of strikes and legal penalties. ${ }^{12}$ Our argument with respect to each of these is that the associated costs are positive functions of $\omega$ on the margin, but that this positive relationship is attenuated by the magnitude of arrears in the rest of the firm's local labor market, $\Omega$. The rationale for each type of cost is fairly straightforward, and we provide evidence on the form of the costs in the empirical analysis below.

\footnotetext{
${ }^{10}$ What we call "public" might also be referred to as "budgetary," as these organizations are dependent on the state budget for their support. We use the term "non-public" (rather than "private") because of full or partial state ownership in many firms.

${ }^{11}$ The model would be little affected were we to assume profit maximization instead, but our assumption of managerial utility maximization is less restrictive, and we are uncomfortable with characterizing Russian firms, in particular, as profit maximizers.

${ }_{12}$ Although we do not assume profit maximization, these costs to the firm reduce the rents that the manager can take out of the firm, implying that they should matter to the manager as well.
} 
A first type of cost arises because delaying wages may increase quits, if the worker responds by leaving for other employments or exiting the labor force altogether. We assume that quits impose costs $Q$ of replacement, associated with the need for hiring, screening, and training new employees (as in, e.g., Oi, 1962; or Stiglitz, 1974). The quit decision is not modeled explicitly, but we assume the manager knows the probability of the worker quitting as a function of $\omega$ and $\Omega$; and we hypothesize a negative impact of $\Omega$ on the worker's quit response to arrears and thus on the firm's marginal cost of arrears. $\Omega$ affects the quit responsiveness to $\omega$ negatively because it reduces the attractiveness of mobility to other firms. Because workers differ in their mobility costs and outside opportunities, we permit the quit function to vary with a set of characteristics such as current compensation (wages and benefits), firm-specificity of skills, mobility costs, and local labor market conditions included in the $Z^{Q}$ vector, so that $Q\left(\omega, \Omega, Z^{Q}\right)$, with $Q_{\omega}>0$ and $Q_{\omega \Omega}<0$.

Wage delays may also affect worker productivity. If morale declines in response to arrears and if effort is not perfectly observable, then workers may be more likely to shirk or even, in extreme cases, to sabotage the firm. Where workers have some discretion over their hours of work, they may reduce the amount of time on the job. We summarize these agency issues under the rubric of "effort costs," $E$, and assume that the manager expects that higher arrears may reduce the worker's productivity through mechanisms similar to those discussed in the efficiency wage literature (Akerlof, 1982; Shapiro and Stiglitz, 1984). Such costs are likely to be greater for some types of workers than for others; we parameterize this heterogeneity as a set of worker characteristics, $Z^{E}$, which could include factors such as the importance of morale for productivity, the difficulty of monitoring, and the degree of independence the worker has in decision-making. We hypothesize that the negative effort effect is attenuated by wage arrears in the rest of the firm's local labor market, $\Omega$, as workers' effort decisions are influenced by their outside alternatives (for instance, if they are caught shirking and fired) and perhaps by their perceptions of the practice's fairness or legitimacy. The effort costs may thus be written as $E\left(\omega, \Omega, Z^{E}\right)$, with the critical properties $E_{\omega}>0$ and $E_{\omega \Omega}<0$.

Another type of cost results if arrears increase strikes and other forms of protest behavior, resulting in costs summarized by $S\left(\omega, \Omega, Z^{S}\right)$. Again, we assume a positive relationship that is attenuated by arrears in the local labor market, such that $S_{\omega}>0$ and $S_{\omega \Omega}<0$. The argument here is that, as with bargaining patterns frequently observed in unionized firms in market economies, 
workers view arrears in the context of what is "normal" in their environment, and they are less likely to protest their own wage delays when their friends and neighbors are also being paid late by their employers. The probability of such behavior is likely to be a function of other characteristics of the firm and worker, particularly the extent of unionization, included in a set of exogenous variables $Z^{S}$. ${ }^{13}$

A final type of cost arises because wage arrears are violations of legal contracts, resulting in possible legal penalties and associated costs $L\left(\omega, \Omega, Z^{L}\right){ }^{14}$ Again, we hypothesize that the probability of these events is positively related to the level of arrears in the firm, but that the strength of the relationship is lower in jurisdictions with higher arrears, such that $L_{\omega}>0$ and $L_{\omega \Omega}$ $<0$. Our main argument is that the legal system in a region may become congested with arrears cases, reducing the probability of punishment, similar to Sah's (1991) analysis of the probability of punishment falling with the crime rate. An additional factor could be a reduced tendency for workers to file lawsuits in an environment of high arrears, both because they would be more likely to perceive arrears as normal and legitimate and because they may be more pessimistic about the chances of resolving the problem through legal channels. When analyzing the impact of local labor market arrears on the relationship between legal penalties and wage arrears of a firm, it is also important to take into account regional variation in the effectiveness of the legal system stemming from factors other than the congestion and lawsuit filing effects, $Z^{L}$.

To summarize, managers face four costs of wage arrears: $E, Q, S$, and $L$, each of which is a function of $\omega, \Omega$, and some shift variables, the vector $Z$. Although the costs are not directly observable, some proxies for the underlying behavior can be measured, which we exploit in our empirical work. For convenience in the exposition of the rest of the model, we consider the sum of the four costs $C(\omega, \Omega, Z)=E\left(\omega, \Omega, Z^{E}\right)+Q\left(\omega, \Omega, Z^{Q}\right)+S\left(\omega, \Omega, Z^{S}\right)+L\left(\omega, \Omega, Z^{L}\right)$, with $C_{\omega}>$ 0 , and $C_{\omega \Omega}<0$ so that the marginal cost is declining with local labor market arrears. $Z=\left(Z^{E}, Z^{Q}\right.$, $Z^{S}, Z^{L}$ ) is a vector of other factors affecting marginal costs (defined so that $C_{\omega Z}>0$ ) such as worker compensation and fringe benefits, skill specificity, search costs, difficulty of monitoring,

\footnotetext{
${ }^{13}$ Our choice of these variables and our analysis of Russian strike behavior more generally are motivated by the broader literature on strikes; see, e.g., Kennan (1986). Our hypothesis that strike behavior in response to arrears is partially a function of arrears in the local labor market is related to the standard notion that employees may gauge their wage and benefit demands to those in some reference firm or sector, as in "pattern bargaining" and use of "pay comparabilities;" see Levinson (1960) for an early discussion, and Lee and Pesaran (1993) for a more recent empirical analysis.

14 The Russian Labor Code explicitly requires on-time payment of wages, and firms may be called to account by the civil courts (when workers file a lawsuit) or the Ministry of Labor's Inspection Service. The latter has been known to fine managers as well as firms, and, more rarely, to order managerial dismissal.
} 
strength of worker organization, functioning of the legal system, and characteristics of the local labor market. Our empirical analysis of model assumptions in Section 5 considers the hypothesis that the marginal cost of $\omega$ is decreasing in $\Omega$ for each component of costs separately. Using proxies for each component, the assumptions may be directly tested: the negative effects of a worker's arrears on measures of her morale and work hours are declining in absolute value with the level of arrears in the local labor market, and the positive effects of arrears on quits, strikes, and legal penalties are similarly attenuated by local labor market arrears.

\subsection{The Reaction Function: $\varpi=f(\Omega, X, Z)$}

The manager chooses $\omega$ to maximize the expected net return to wage arrears $\pi$.

$$
\max _{\omega} \pi=R(\omega, X)-C(\omega, \Omega, Z)
$$

where $\omega$ is the amount of back wages owed to the worker and $\Omega$ is the average amount of wage arrears in the local labor market outside the firm.

The first and second order conditions for the manager's problem (1) are as follows:

$$
\begin{aligned}
& \frac{\partial \pi}{\partial \omega}=r(X)-C_{\omega}(\omega, \Omega, Z)=0 \\
& \frac{\partial^{2} \pi}{\partial \omega^{2}}=-C_{\omega \omega}<0
\end{aligned}
$$

implying the following optimality condition:

$$
r(X)=C_{\omega}(\varpi, \Omega, Z) .
$$

The reaction function can be derived as:

$$
\varpi=f(\Omega, X, Z) .
$$

Total differentiation of the first order condition yields:

$$
r_{X} d X-C_{\omega \omega} d \omega-C_{\omega \Omega} d \Omega-C_{\omega Z} d Z=0
$$

Taking each of the exogenous variables $X$ and $Z$ in turn, and making use of the assumptions and the result in equation (3), we can derive the following comparative static results for the impact on $\omega$ : 


$$
\begin{aligned}
& \frac{d \omega}{d X}=\frac{r_{X}}{C_{\omega \omega}}>0 \\
& \frac{d \omega}{d Z}=\frac{-C_{\omega Z}}{C_{\omega \omega}}<0 .
\end{aligned}
$$

Thus, wage arrears should be positively related to the firm's cost of capital and to the ability of managers to appropriate cash flow and earn private benefits. They should be negatively related to the difficulty of monitoring the worker, to the value of the worker's outside alternatives, to the strength of worker organization, and to the effectiveness of the legal system. Finally, factors that reduce quit rate increase the probability of having wage arrears (specific human capital, employee ownership, high search and mobility costs, etc.).

Differentiating the reaction function (5) with respect to $\Omega$ (while holding constant the variables in $X$ and $Z$ ) yields:

$$
\frac{d \omega}{d \Omega}=-\frac{C_{\omega \Omega}^{(-)}}{C_{\omega \omega}}>0 .
$$

Thus, a direct implication of our model is that wage payment decisions exhibit positive neighborhood effects. In the next section, we present our empirical estimates of a linear reaction function, followed by an empirical analysis of model assumptions (in Section 5) and an example of a nonlinear reaction function implying the possibility of multiple equilibria (in Section 6).

\section{Estimating the Linear Reaction Function}

Our first tests of the model focus on the most important implication, the positive slope of the reaction function $(\partial \omega / \partial \Omega>0)$. We also examine the model implications that proxies for $X$ raise $\omega$ and that proxies for $Z$ lower $\omega$, while postponing analysis of the feedback loops and other model assumptions until the next section. We first discuss our identification strategy and then present results.

\subsection{Identification Strategy}

To test for positive feedback in the reaction function, we assume a linear functional form for equation (5). Estimating the function directly by ordinary least squares (OLS) raises the standard identification problems in any model of social interactions, which are discussed by Manski (1993) and Moffitt (2001). As an illustration of these potential problems, consider the 
following model of endogenous interactions for two firms (for simplicity, each with one employee), indexed by $i$ and $k$ :

$$
\begin{aligned}
& \omega_{i j t}=\beta_{0}+\beta_{1} \Omega_{(-i) j t}+\beta_{2} X_{i j t}+\beta_{3} Z_{i j t}+\tau D_{t}+u_{i j t} \\
& \omega_{k j t}=\beta_{0}+\beta_{1} \Omega(-k) j t+\beta_{2} X_{k j t}+\beta_{3} Z_{k j t}+\tau D_{t}+u_{k j t}
\end{aligned}
$$

where $\omega_{i j t}$ is the number of unpaid monthly wages of firm $i$ in district $j$ in period $t$; $\Omega_{\text {(-ij)t }}$ is the level of wage arrears in the rest of the firm's local labor market (district) $j$ in period $t ; X_{i j t}$ and $Z_{i j t}$ are the vectors of observable factors affecting returns to and cost of using wage arrears, respectively; $D_{t}$ is a set of year dummy variables; and the $u$ 's are error terms.

A first problem could arise if error terms are correlated because of correlated unobservables. Examples of such variables that could produce $\operatorname{Cov}\left(u_{i j t}, u_{k j t}\right) \neq 0$ in our model include differences across districts in resources, demand conditions, legal environment, or social norms such as tolerance towards contract violation. A second potential reason for correlation of the error terms could be endogeneity due to firm interdependence in the level of wage arrears: $\omega_{i j t} \Rightarrow \Omega_{(-k) j t} \Rightarrow \omega_{k j t} \Rightarrow \Omega_{(-i) j t} \Rightarrow \omega_{i j l}$ what Manski (1993) refers to as the "reflection problem." In these cases, $\beta_{O L S}$ is biased and inconsistent.

The problem of correlated unobservables may be handled by exploiting the panel features of the data.

$$
\omega_{i j t}=\beta_{1} \Omega_{(-i) j t}+\beta_{2} X_{i j t}+\beta_{3} Z_{i j t}+\tau D_{t}+\theta_{j}+\varepsilon_{i j t},
$$

where $X_{i j t}$ and $Z_{i j t}$ include time-varying observable characteristics; $\theta_{j}$ are local labor market (district) fixed effects with observable (e.g., urban characteristics, local infrastructure, and access to resources) and unobservable (e.g., common preferences and social norms) components. We also exploit the presence of many firms with multiple workers in our data and the existence of multiple observations on each worker in the panel, permitting us to include firm and worker fixed effects and take into account variation in fixed unobserved heterogeneity along these dimensions.

The second issue is how to identify the firm interaction effect. Our identification strategy, inspired by a suggestion concerning social interactions in Moffitt (2001), is to search for interventions that alter the wage arrears practice for some workers but not for the others. To this end, we exploit the fact that non-payment of wages in the public sector is driven by a 
different process - governmental financing and revenue-sharing decisions-than wage delays in the non-public sector, which are driven by the considerations in our model.

Thus, the identification solution is to use arrears practice in the public sector to identify neighborhood effects in the non-public sector. The model becomes

$$
\begin{aligned}
& \left\{\begin{array}{l}
\omega_{i j t}=\beta_{1} \Omega_{(-i) j t}+\beta_{2} X_{i j t}+\beta_{3} Z_{i j t}+\tau D_{t}+\theta_{j}+\varepsilon_{i j t} \\
\omega_{k j t}=\beta_{1} \Omega_{(-k) j t}+\beta_{2} X_{k j t}+\beta_{3} Z_{k j t}+\tau D_{t}+\theta_{j}+\varepsilon_{k j t} \\
\omega_{p j t}=\beta_{2} X_{p j t}+\beta_{3} Z_{p j t}+\tau D_{t}+\theta_{j}+\varepsilon_{p j t}
\end{array}\right. \\
& \operatorname{Cov}\left(\varepsilon_{i j t}, \varepsilon_{p j t}\right)=\operatorname{Cov}\left(\varepsilon_{k j t}, \varepsilon_{p j t}\right)=0
\end{aligned}
$$

where $p$ denotes public sector. The identifying assumption here is that $\Omega_{(-p) j t}$, the level of wage arrears in the rest of the firm's local labor market (district) $j$ in period $t$, does not enter the equation for $\omega_{p j t}$ - in other words, that wage arrears in the public sector are determined by bureaucratic decisions in the federal and regional governments that are unrelated to arrears of non-public firms in the local area. We provide further discussion and evidence on the validity of this assumption in Section 5.2 below.

In these equations (11), $\Omega_{\text {(-ij)t }}$ equals the sum of average wage arrears in the public and non-public sectors, weighted by the share of workers in the corresponding sectors:

$$
\Omega_{(-i) j t}=\frac{1}{N}\left(\sum_{k \neq i} \omega_{k j t}+\sum_{p} \omega_{p j t}\right)=\bar{\omega}_{k j t}\left(1-n_{p}\right)+\bar{\omega}_{p j t} n_{p},
$$

where $\bar{\omega}_{k j t}$ and $\bar{\omega}_{p j t}$ are the average wage arrears in the public and non-public sectors respectively (again excluding firm $i$ ), and $n_{p}$ is the share of workers in the public sector. The first term in $\Omega_{(-i) j t}$ is endogenous, while the last term is exogenous. Therefore, our method employs $\bar{\omega}_{p j t} n_{p}$, the average arrears in the public sector weighted by the share of workers in the public sector in district $j$, as an instrument. This variable captures both the magnitude of average arrears that appear exogenously and the relative share of this exogenous component in total regional arrears.

A third potential identification issue in estimating the wage arrears reaction function is the possibility that the reference group (district in our case) is endogenous (Moffitt, 2001). Analogous to the choice of peer group in studies of teenage behavior (e.g., Evans, Oates, and Schwab, 1992) it is possible that firms and workers sort themselves across districts in terms of 
their returns, costs, and tolerance of arrears. The clustering of arrears within districts might merely reflect the tendency for similar agents to locate close to one another. Our inclusion of district-level fixed effects controls for this possibility, but in any case such geographic sorting seems quite implausible, particularly in the Russian case. An oft-noted feature of Russian labor markets is the low geographic mobility of labor, possibly due to information problems, poorly functioning housing markets, or liquidity problems of Russian workers (Mitchneck and Plane, 1995; Heleniak, 1997; Friebel and Guriev, 2002; and Andrienko and Guriev, 2004). All evidence implies that Russian regions are poorly integrated, and worker (and firm) mobility across regions can act only slowly to affect regional differences.

\subsection{Results}

Our model and discussion of identification issues suggest the value of alternative approaches to estimation. We provide OLS results of the reaction function as a baseline, and then report various combinations of instrumental variables (IV) and worker, firm, and district fixed effects. Whenever possible, we compute robust standard errors that are adjusted for clustering on districts. These estimation results are shown in Table 4 . In fact, the estimated $\beta$ (the coefficient on $\Omega$ ) varies rather little across specifications, remaining in the range from 0.77 to 1.03. Instrumenting and including fixed worker effects raises estimated $\beta$ slightly, while including fixed effects for districts or firms tends to reduce it slightly. The analysis provides strong evidence for neighborhood effects in the decision to violate the wage contract and delay payment.

Many of the results for the $Z$ variables included in the table are statistically insignificant, but the negative effect of tenure is consistent with the interpretation that longer tenured workers tend to have relatively poor outside alternatives (Lehmann, Wadsworth, and Acquisti, 1999; Earle and Sabirianova, 2002). The magnitude of the point estimates are not large, however, suggesting an additional overdue wage debt of about one month for a worker with 30 years of tenure compared to a newly hired worker. The hourly wage enters only weakly, a relationship we return to in Section 5.2. A final noteworthy result is the positive impact of small share ownership on arrears in every specification. One interpretation of this finding is that managers are seeking to acquire shares from their workers, as discussed in Earle and Sabirianova (2002). Such an interpretation is inconsistent with the notion that wage arrears are the result of some 
voluntary agreement between workers and firms, again a subject to which we return in Section 5.2.

The bottom part of the table shows the first stage results for the IV estimates. The instrument $\left(\bar{\omega}_{p j t} n_{p}\right)$ is highly statistically significant and, as hypothesized, is estimated to have a positive effect on $\Omega_{(-i) j t}$.

\section{Feedback Loops and Model Assumptions}

This section presents an empirical analysis of model assumptions. Section 5.1 considers the costs to the manager of using wage arrears and the possibility that these produce feedback loops that may increase the strength of neighborhood effects. Section 5.2 considers two important exogeneity assumptions: the exogeneity of the wage in the arrears equation and the exogeneity of arrears in the public sector.

\subsection{Estimating the Feedback Loops}

We draw upon both the worker and the firm data to construct proxy variables for the four types of costs of arrears discussed in the model, and summary statistics for these variables are displayed in Tables 2 and 3. The variables for "quits," "hours of work," and "desire to switch jobs” are measured from the RLMS, while “quit rate,” "strikes and other forms of protest,” and "legal penalties" are drawn from the enterprise survey. The first two variables proxy effort decisions by workers: work hours are reported actual hours on the job, and "desire to switch jobs” is a dummy variable in response to a direct question on this issue. We argue that these proxy for morale and job satisfaction, variables likely to influence effort; in addition, it is sometimes argued that Russian workers reduce their hours in response to arrears (Aslund, 1997), providing an additional motivation for examining the effects of $\omega$ and $\Omega$ on work hours.

We analyze two measures of quits. The first, based on the RLMS panel, defines a quit as no longer working for the employer two years later. This measure includes all types of separations, but available evidence strongly indicates that the share of involuntary separations is very low in Russia-generally less than 10 percent of all separations. ${ }^{15}$ The second measure, based on the firm survey data, includes voluntary separations only, is expressed as a ratio to average firm employment, and refers to a one-year period.

\footnotetext{
${ }^{15}$ Brown and Earle (2003), for example, report the average separation rate in Russian manufacturing from 1990 to 1999 was 26.51 percent, but the layoff rate was only 2.27 percent.
} 
The final two potential costs of arrears are also measured at the firm level. "Strikes" refer not only to formal work stoppages but also to other forms of protests, such as hunger strikes and work slowdowns. The data imply they are much more common in firms reporting wage arrears than in those not, and wage arrears were by far the most commonly cited reason for strikes by firms reporting them in response to a direct question. "Legal penalties" refer specifically to fines for wage arrears, which may be imposed by either a civil court or the Inspection Service. Both of these are dummy variables, and their means over the firm-years in the sample are shown in Table 3. The incidence of both variables is very low in the early 1990s but becomes more substantial in the second half of the decade.

Recall from Section 3.1 the model assumptions of $C_{\omega}>0$ and $C_{\omega \Omega}<0$ : the costs to using wage arrears exhibit positive feedback in the sense that the costs of arrears are reduced on the margin when other firms in the local labor market tend to have higher arrears. If this is correct, then each of these types of costs represents a feedback loop that contributes to self-propagation of wage arrears.

The critical assumption of a negative cross-partial derivative may be directly tested using an interaction term in each equation. The relationship between the costs of using wage arrears and the wage arrears environment can be presented in linear form as follows:

$$
C_{i j t}=\beta_{\omega} \omega_{i j t}+\beta_{\Omega} \Omega(-i) j t+\beta_{\omega} \omega_{i j t} \Omega_{(-i) j t}+\gamma Z_{i j t}+\tau D_{t}+\theta_{j}+\varepsilon_{i j t},
$$

where $C_{i j t}$ are proxy measures for wage arrears costs such as hours of work, desire to switch jobs, quits, strikes, and legal penalties; $\omega_{i j t}$ is the number of unpaid monthly wages of individual $i$ working in district $j$ in period $t ; \Omega_{(-i) j t}$ is the level of wage arrears in the rest of the firm's local labor market (district) $j$ in period $t ; Z_{i j t}$ is a vector of time-varying observable individual characteristics (hourly wage rate, family income, schooling, tenure, occupation, and employee ownership) and firm characteristics (industry, union density, fringe benefits, and training costs); $D_{t}$ is the set of year dummy variables; and $\theta_{j}$ are local labor market (district) fixed effects.

Table 5 shows estimates for the functions with quit behavior, the desire to change jobs, and hours of work as dependent variables from the worker survey. The impact of $\omega$ on a worker's hours and desire to switch jobs is reduced by $\Omega$ (so that $E_{\omega \Omega}<0$ ). Computing $\partial($ Hours $) / \partial \omega$ at alternative levels of $\Omega$, we find that workers in low- $\Omega$ regions reduce their hours in response to their own arrears, so that if $\Omega=0$, hours fall 1.46 hours per month for each one 
month increase in $\omega$. But $\partial$ (Hours) $/ \partial \omega$ falls as $\Omega$ rises, and at $\Omega=8.6$ months, the effect vanishes entirely. Similarly, the probability that an individual reports a desire to switch jobs, our proxy for job satisfaction, increases by 2.4 percent for each month of $\omega$ in regions where $\Omega=0$. Given an overall average probability of 36 percent, this effect implies that an individual who has six months arrears and lives in a low arrears region would be 50 percent more likely to desire a job change compared to an otherwise identical neighbor with no wage arrears. But the effect declines with $\Omega$ such that the point estimates suggest it becomes negligible at about $\Omega=10$.

Table 5 results concerning the vector of $Z$ controls in the regressions are fairly standard: the hours equation shows a slight tendency towards backward-bending in the hourly wage rate (the magnitude suggests that a 1000 ruble increase in the wage, about 11 percent, would decrease hours by 1.25 hours per month), while non-labor (family) income has a negative sign, and male gender, schooling, and age are all positively associated with hours. The regression for desire to switch jobs shows that the probability declines with the contractual wage and with job tenure.

Table 5 also shows the estimated quit function using individual data. Again, the results imply $Q_{\omega}>0$ and $Q_{\omega \Omega}<0$ for this component of costs. The estimated derivative of the quit probability with respect to $\omega$ implies that workers quit in response to their own arrears when $\Omega$ is less than ten months, but when $\Omega$ is greater, the quit response to $\omega$ becomes negative. This clear finding in the data provides additional strong evidence for our hypothesis that wage arrears are strategic complements for managers of firms operating in the same local labor market. Results for the $Z$ controls show that male gender is positively associated while schooling and tenure are negatively associated with the quit probability.

The estimates of the cost feedback functions using the firm survey data are shown in Table 6. In these regressions, we specify the $Z$ vector to include industry, union density (percentage of employees who are union members), provision of fringe benefits (training, kindergartens, and housing), and training costs for new employees (measured as number of days required in initial training). Unionism may influence the propensity to strike, and it may influence quit decisions (exit versus voice strategies) as well (e.g., Freeman, 1980). Fringe benefits have been argued to influence the attachment of workers to their employers (Layard and Richter, 1995; and Friebel and Guriev, 2002). Training requirements play an important role in replacing workers who have quit. The summary statistics for all these controls are presented in Table 3. 
Because strikes and legal penalties did not occur in some of the districts, we cannot include district fixed effects in the probit analysis. Instead, we use the type of location (capital city, other city, and non-city) and proxies for the legal environment. The latter measures are drawn from data of the Russian Ministry of Labor's Inspection Service, and they pertain to the subject of the Russian Federation in which the firm is located in the year 1997. The first variable reports the ratio of the uncollected fines to the total number of fines assessed on managers because of labor violations. We interpret this variable as reflecting (inversely) the strength of the legal system in carrying out at least those punishments it does assess: managers would have relatively little to fear in regions where this ratio is high. Although the mean of the variable is low, the standard deviation is substantial. The second variable is the ratio of the number of cases where wage arrears were paid off to the number of violations found by the Inspection Service. This variable we interpret as directly related to the enforcement regime, and its low level indicates that even when the policing agency has discovered a violation it is rather unlikely to be remedied. The lower level for firms reporting wage arrears, relative to those reporting none, is consistent with legal congestion preventing the Inspection Service from enforcing the labor laws and contracts. These two variables are included in the $Z$ vector of controls when we estimate the cost function for legal penalties.

Again the data show that $\Omega$ tends to lessen the impact of $\omega$ on costs to the firm of using arrears: $Q_{\omega \Omega}<0, S_{\omega \Omega}<0$, and $L_{\omega \Omega}<0$. The data provide consistently strong support for the negative cross-derivative, implying positive feedback to the use of the wage arrears practice. The magnitudes imply that the quit rate and the probability of protesting wage arrears declines to zero when $\Omega=5$; with respect to legal penalties the probability reaches zero at $\Omega=4$. These costs of wage arrears are virtually vanishing in the observed range of behavior.

The control variables of union density, training provision, and the level of training costs are estimated to reduce the quit rate. The effect of union density on the strike probability is statistically insignificant, a result consistent with some observers' assessments that Russian unions tend to be weak (e.g., Gimpelson and Lippoldt, 2001). The fraction of cases when managers failed to pay assessed fines on time is estimated to have a negative impact on the probability of legal penalties, which we interpret as a reflection of the effectiveness of local legal institutions. The negative impact of the second variable, the fraction of cases when arrears were paid off after the violation was discovered, is a bit more puzzling: it may simply reflect the fact 
that penalties are less likely to be assessed when managers quickly pay after they are found out. In any case, the results for all four components of costs strongly support the hypothesis of a positive feedback loop in each case, suggesting there may be increasing returns to the use of wage arrears.

\subsection{Other Model Assumptions}

We argue in this paper that it is reasonable to treat wage rates as exogenous in the data generating process for wage arrears. The assumption follows from understanding the institutions of wage determination and contract negotiation in Russia, where wages in large companies, responsible for most arrears, are determined in collective bargaining agreements at a frequency of one or two years. The decisions on arrears - whether to delay payment, to pay partial wages, and to repay any overdue back wages - are taken monthly. Thus, at the moment of deciding on arrears, the wage is predetermined. Moreover, there is no negotiation of wage arrears in collective bargaining. The concept of such a negotiation is a logical self-contradiction involving a contract to violate a contract. It would be completely unenforceable, even more than the contractual wage rates themselves. ${ }^{16}$ Wage arrears cannot be specified, agreed to, and fixed $e x$ ante; by their very nature, they are noncontractible.

Nevertheless, to provide some empirical evidence on this question, let us assume for the moment that it were possible for the worker and the firm to agree on both a contractual wage rate and a magnitude of wage arrears. If arrears are a disamenity for workers-like danger, risk of layoff, or lack of fringe benefits - then there should be a positive compensating differential associated with them: they should be positively related to contractual wages. ${ }^{17}$ The standard way of estimating the equalizing difference that workers place on such job characteristics is the familiar hedonic wage function (e.g., Rosen, 1974), including wage arrears as an independent variable, and results from estimating various versions of such a function are displayed in Table 7. In some specifications, we instrument the worker's $\omega$ with the district's $\Omega$. While the wage equations otherwise show fairly standard shapes (large male premium, positive returns to schooling, concave profile in experience), in no case does the estimation yield a positive coefficient on $\omega$. The data provide no support for the existence of a trade-off between wage rates

\footnotetext{
${ }^{16}$ Trade union leaders interviewed by the authors in Moscow completely rejected the possibility that the extent of wage contract violations could ever be negotiated with management.

${ }^{17}$ It stands to reason that the worker's utility would be decreasing in the uncertainty of the wage, and empirical evidence from public opinion polls has demonstrated that Russian workers consistently place the problem of wage arrears as one of the fundamental problems facing their country (see, e.g., Javeline, 2003).
} 
and wage arrears, and by implication they reject the notion of an implicit market in the extent to which firms keep their wage promises. ${ }^{18}$

Another assumption, important for our identification strategy in estimating the neighborhood effects in Section 4 above, is that the model applies to the non-public sector but not to employers supported by the state budget, such as schools, hospitals, governmental administration, and military producers. Indeed, while data on the early period are scarce, we believe the initial burst of arrears in Russia was caused by the sequestration of budgetary funds by the Ministry of Finance in the early and mid-1990s. Only very incomplete accounts of the extent of sequestration are available, but according to many observers the amounts were large. ${ }^{19}$ According to the Institute for the Economy in Transition (1994, p. 35), for example, every expenditure line in the fourth quarter of the 1993 federal budget was sequestered by 20 percent. Rather than shutting the government down, as occasionally happens in the U.S. during budgetary disputes between the president and Congress, the Russian government continued to operate, government contractors continued to supply government orders, and state employees continued coming to work even when they began to be paid irregularly. Unfortunately, detailed data on these early stages of wage arrears are unavailable to substantiate fully our allegation that the state played the role of leader in spreading the practice.

We are, however, able to examine the related identifying assumption in our empirical work that public sector arrears are not subject to the same neighborhood effects as are arrears in the non-public sector. Contrary to the argument above, let us assume that public sector wage payments are influenced by $\Omega$, and estimate the magnitude of this effect. The results are shown in Table 8. Panel A has results for $\Omega$ in all firms in the district, while Panel B contains the coefficient on $\Omega$ in the non-public sector only; which of these is more appropriate depends on whether the public sector should be treated as a single employer or as multiple decision-makers. In any case, the results show much lower coefficients for an influence of non-public arrears on the level of public sector arrears. The fact that the coefficients are positive does suggest that some reverse feedback from non-public arrears to the public sector may be operating, but this feedback is clearly much weaker than the responsiveness of arrears in the non-public sector.

\footnotetext{
${ }^{18}$ Furthermore, none of our results in Tables 4-6 and 8-9 are altered more than slightly if we simply drop the wage rate from the equations.

${ }^{19}$ The motive for sequestration was to reduce the budget deficit and inflation following price liberalization in 1992; the deficit target figured strongly in IMF loan agreements at the time, and some policymakers even boasted of sequestration as a clever way to satisfy conditionality.
} 


\section{Estimating a Nonlinear Model of Wage Arrears Interactions}

Returning to the model in Section 3, we obtain the second derivative of the reaction function:

$$
\frac{d^{2} \omega}{d \Omega^{2}}=\frac{C_{\omega \omega \Omega} C_{\omega \Omega}^{(-)}-C_{\omega \Omega \Omega} C_{\omega \omega}^{(+)}}{C_{\omega \omega}{ }^{2}} \geq 0 .
$$

The second derivative may be positive as well as negative. Multiple equilibria are more likely, of course, if the sign switches. Such a case, where the second derivative is initially positive and then turns negative after $\Omega$ exceeds the inflection point $\Omega_{l}$, is shown in Figure 1 .

To motivate this case more fully, we next consider a particular functional form for the cost function, one from which we derive an estimable reaction function that permits the possibility of multiple equilibria.

\subsection{A Particular Functional Form for Estimation}

Consider the following special form of the cost function:

$$
C=\omega \cdot\left(a \omega-b \Omega-c \Omega^{2}+d \Omega^{3}+e Z\right),
$$

which is the simplest that permits the possibility of multiple symmetric Nash equilibria, as we show below. We will again assume that the cost function satisfies the following features:

$$
\begin{aligned}
& C_{\omega}=2 a \omega-b \Omega-c \Omega^{2}+d \Omega^{3}+e Z=a \omega+\frac{C}{\omega}>0 \\
& C_{\Omega}=\omega\left(-b-2 c \Omega+3 d \Omega^{2}\right)<0 \\
& C_{\omega \omega}=2 a>0 \quad \Rightarrow \quad a>0 \\
& C_{\omega \Omega}=-b-2 c \Omega+3 d \Omega^{2}=\frac{\stackrel{(-)}{C_{\Omega}}}{\omega}<0 \\
& C_{\omega Z}=e>0
\end{aligned}
$$

Parameters $a$ and $e$ are positive by virtue of our earlier assumptions, but we also hypothesize that $c$ and $d$ are positive, while the sign of $b$ is ambiguous, for reasons that we discuss shortly. The first-order condition of maximizing the objective function implies the equality of marginal return and marginal cost associated with wage arrears:

$$
\begin{aligned}
& \max _{\omega} \pi=r \omega-\omega\left(a \omega-b \Omega-c \Omega^{2}+d \Omega^{3}+e Z\right) \\
& r=2 a \omega-b \Omega-c \Omega^{2}+d \Omega^{3}+e Z
\end{aligned}
$$

From the first order condition we can derive an estimable reaction function: 


$$
\varpi=\frac{b \Omega+c \Omega^{2}-d \Omega^{3}+r-e Z}{2 a},
$$

where $\varpi$ is a cubic function of $\Omega$.

The reaction function exhibits positive feedback:

$$
\frac{\partial \varpi}{\partial \Omega}=\frac{b+2 c \Omega-3 d \Omega^{2}}{2 a}=-\frac{C_{\omega \Omega}^{(-)}}{2 a}>0 .
$$

But the sign of the second derivative is ambiguous:

$$
\frac{\partial^{2} \varpi}{\partial \Omega^{2}}=\frac{c-3 d \Omega}{a} \underset{<}{<},
$$

depending on $c, d$, and $\Omega$. For fixed $c$ and $d>0$, the reaction function exhibits a cubic S-shape with inflection point at $\Omega_{i}=c / 3 d$. At lower levels of local labor market arrears $(\Omega<c / 3 d)$ the response function is convex, while at higher levels it is concave. We test these implications on the shape of the reaction function in our empirical analysis below.

\subsection{Equilibrium Wage Arrears}

In symmetric Nash equilibrium, where all firm managers in a local labor market are assumed to face identical return and cost functions and where they take each other's actions as given, the level of firm wage arrears must be equal to the level of regional wage arrears $\left(\omega^{*}=\Omega^{*}\right)$, which implies

$-d \omega^{*^{3}}+c \omega^{*^{2}}+(b-2 a) \omega^{*}+r-e Z=0$.

It is possible to solve this equation analytically for three equilibria in terms of $a, b, c, d, e$, $r$, and $Z$, but the equations describing the solutions are very long (several pages each). To simplify for illustrative purposes, we note that $r-e Z>0$ implies that even if no other firms in the region have wage arrears $(\Omega=0)$, the net return to wage arrears is still positive, implying $\omega>0$. Since most economies are characterized by punctual payment of wage obligations, we will normalize the results, assuming $r=e Z$, which also permits us to write out analytical solutions for wage arrears equilibria in this special case. Under this assumption, the three symmetric Nash equilibria are:

$$
\omega_{1}^{*}=0
$$




$$
\begin{aligned}
& \omega_{2}^{*}=\frac{c-\sqrt{c^{2}+4 d(b-2 a)}}{2 d} \\
& \omega_{3}^{*}=\frac{c+\sqrt{c^{2}+4 d(b-2 a)}}{2 d} .
\end{aligned}
$$

One equilibrium involves zero firm wage arrears at zero regional wage arrears, while positivity of two requires that $4 d(b-2 a)<0$, implying restrictions on $a$ and $b$ such that $b / 2 a<1$. The parameter $b$ may be positive or negative, although our hypotheses imply a generally positive slope of the reaction function.

We may characterize $\omega_{1}{ }^{*}$ as the "punctual payment equilibrium," $\omega_{2}{ }^{*}$ as the "critical mass" or "threshold equilibrium," and $\omega_{3}{ }^{*}$ as the "late payment” or "wage arrears equilibrium." An analysis of the stability of these three equilibria in the Appendix shows that $\omega_{1}{ }^{*}$ and $\omega_{3}{ }^{*}$ are stable, while $\omega_{3}{ }^{*}$ is unstable. Figure 2 shows the symmetric Nash equilibria and the dynamics implied by the model. In the range where $\omega_{1}{ }^{*}<\Omega<\omega_{2}{ }^{*}$, a self-interested manager will choose $\omega<\Omega$, so optimizing behavior by all managers will tend to drive down $\Omega$. Beyond $\omega_{2}{ }^{*}$, managerial behavior will tend to push up $\Omega$ until it reaches $\omega_{3}{ }^{*}$, the stable late payment equilibrium.

\subsection{Nonlinear Estimation Results}

Multiple equilibria may arise when the reaction function has an S-shape, so that at low levels of $\Omega, \partial^{2} \omega / \partial \Omega^{2}>0$, while at higher levels $\partial^{2} \omega / \partial \Omega^{2}<0$. The functional form of the manager's objective that we have employed as an example (equation (1') above) suggests a cubic form for the reaction function, with alternating signs on the coefficients in the polynomial on $\Omega$. More specifically, we can test that the critical parameters $c$ and $d$ are both positive, while $b / 2 a<1$.

We therefore estimate the reaction function (5'). Decomposing the $Z$ vector of other characteristics of workers and firms affecting wage arrears into observable and unobservable components leads directly to our estimating equation:

$$
\omega_{i}=\beta_{0}+\beta_{1} \Omega_{i}+\beta_{2} \Omega_{i}^{2}+\beta_{3} \Omega_{i}^{3}+\beta_{4} X_{i}+\beta_{5} Z_{i}^{\prime}+\xi_{i}
$$

where we use the subscript $i$ to index individual workers, and where $\beta_{1}=b / 2 a, \beta_{2}=c / 2 a$, and $\beta_{3}$ $=-d / 2 a, \beta_{4}=r^{\prime}\left(X_{i}\right) / 2 a$ and $\beta_{5}=-e / 2 a$. We have decomposed the vector of $Z$ controls to include a 
constant, $\beta_{0}$, a vector of observable characteristics, $Z_{i}$, and a residual reflecting an unobserved component in the cost function, $\varepsilon_{i}$; thus, $Z_{i}=\beta_{0}+Z_{i}{ }^{\prime}+\varepsilon_{i}$, and $\xi_{i}=\varepsilon_{i} / 2 a$.

Brock and Durlauf (2001) argue that a nonlinear model of social interactions similar to equation (19) is generically identified, but to examine robustness we report both OLS and FE estimates. In fact, as in the linear case, the inclusion of correlated effects at the district, firm, and worker level does little to alter the results, which are shown in Table 9. The results for $X$ and $Z$ variables are very similar to those in Table 4 and therefore are not displayed in Table 9, which contains our estimates of equation (19).

Concerning the polynomial in $\Omega$, one of the less obvious predictions of the theoretical model, emerging from the discussion above, was that $b / 2 a=\beta_{l}<1$. This implication is satisfied by all the estimates in Table 9, and in all cases we can reject the hypothesis that $\beta_{1}=1$ at the one percent level. This is also a necessary condition for stability of the extreme equilibria. The signs of the estimates of $c$ and $d$ are also consistent with the theoretical model in all four estimated models, and they are statistically significant.

The nonlinear estimation results continue to support the hypothesis of positive neighborhood effects over most of the relevant range. Only when district fixed effects are included is $\beta_{l}$ statistically significantly less than zero, and even in this case, the reaction function is estimated to have a positive slope for $\Omega>1.6$. In all cases, the point estimates of the coefficients imply an S-shaped reaction function.

\subsection{Simulating Symmetric Nash Equilibria}

Whether even an S-shaped reaction function produces multiple equilibria depends on the magnitudes of the parameters. Using the estimated parameters of the empirical reaction function, we may simulate symmetric Nash equilibria and calculate the levels of arrears consistent with the two stable equilibria and with the unstable critical mass threshold.

Figure 3 graphs the estimated reaction function, taking the average of $\beta_{0}+\beta_{4} X_{i}^{\prime}+\beta_{5} Z_{i}{ }^{\prime}$ across all individuals in the sample, which then becomes the intercept for the plotted relationship. Under the assumption of symmetric Nash behavior in local labor markets, it is straightforward in principle to solve the estimated reaction functions for the set of average equilibria across regions. Figure 3 does this in the simplest way, by finding the intersection between the reaction function and a $45^{\circ}$ ray from the origin. 
As is evident from the figure, the results suggest there are indeed multiple equilibria. The average punctual payment equilibrium in Russian regions involves less than one monthly wage debt, the critical mass equilibrium is 5.5 months, and the late payment equilibrium is 9.5 months. The estimates imply stability of the extreme equilibria $\omega_{1} *$ and $\omega_{3}{ }^{*}$ and instability of the threshold $\omega_{2}{ }^{*}$. Thus, the data not only provide support for the model's most important predictions of positive feedback and multiple equilibria, but also for some of the model's crucial details.

\subsection{Equilibrium Selection, Robustness, and Welfare}

If there are multiple equilibria in wage arrears, how do countries or regions get into the punctual payment or the late payment equilibrium? A natural candidate for selecting the equilibrium would be a large employer, big enough to move the equilibrium from one side of the critical mass threshold to the other by setting a standard that other employers follow. In the Russian case, we would argue that role was played by the state, which as we have discussed initiated late payments on a large scale by budgetary sequestration to reduce the fiscal deficit. It is notable that the share of employment accounted for by the public sector was actually growing through most of this standard-setting period. ${ }^{20}$

How robust is the late payment equilibrium? For instance, while our analysis has focused on symmetric Nash equilibria, what prevents some firm, say a new entrant, from violating the late-payment norm by offering workers a lower wage, but one paid regularly on time? Our model shows that identical firms will not defect from the late payment equilibrium, but in practice there is likely to be heterogeneity, particularly in the case of new start-ups. Firms with profitable opportunities seeking to hire new employees may try to build a reputation for punctual payment if workers care about this characteristic of their jobs.

While such a process may sometimes occur in a number of regions of Russia, in order to explain why it does not unravel the late payment equilibrium in regions with persistently high arrears we must call upon other aspects of the Russian environment, including the severe recession and the continual instability and illiquidity. The large fall in output and consumption has reduced the profitability of entry, and the continual instability has made it difficult for firms to establish reputations. We can imagine a signaling game in which there are two types of firms:

20 According to OECD (1997), employment in public administration grew steadily from 663,000 in 1990 to $1,087,000$ in 1995 , or from 0.88 to 1.64 percent of total employment. 
in one type, where prospects are poor, managers simply try to steal wages; in the others, which have profitable projects, they try to pay them and build a reputation in order to increase effort and reduce turnover. But the type of firm is unobservable to workers, and all managers can announce (as they do in reality) their most sincere intentions to pay wages "as soon as the firm has money." In this situation, the ability of the second type of managers to distinguish themselves from the first type amounts to the possibility for existence of a separating equilibrium. If economic instability is so great that occasional shocks hit every firm with some probability, rendering them temporarily unable to pay, then firms cannot build a reputation and workers may not be able to distinguish the firm types in practice. This analysis is outside our formal model, and it is very difficult to verify empirically, but it does explain why a late payment equilibrium may be robust even when new entry and firm heterogeneity are permitted.

Given our argument that the wage payment practice may exhibit multiple equilibria, what are the welfare characteristics of the late versus the punctual payment equilibrium? Layard and Richter (1995) and OECD (1997) have praised the use of wage arrears as a way of achieving wage flexibility and low unemployment in Russia. Leaving aside the question of the social desirability of wage flexibility, however, it seems to us that wage arrears are far from being a socially efficient mechanism for bringing about a given effective change in the real wage.

As a first welfare consideration, we have noted that wage arrears are unevenly spread across regions and households, and thus their social consequences tend to be concentrated in certain groups. Second, wage arrears reduce utility more than equivalent wage cuts because of the associated uncertainty concerning the timing and probability of eventual payment. Third, arrears may sometimes actually impede mobility, particularly where arrears are widespread in the local labor market; these areas are also likely to be those where mobility-geographic and industrial—is most needed. Thus, wage arrears may actually retard the reallocation of labor that is critical to the transition process.

It seems to us, however, that the major consideration in a normative evaluation of arrears stems from the fact that labor contracts are the most important contracts for most individuals. The violation of those contracts reduces confidence in other labor and nonlabor contracts into which the individual might enter. In short, wage arrears may undermine the development of contract enforcement and rule of law. North (1990) has argued these are critical institutions in promoting impersonal exchange, which in turn explains much about differences in economic 
growth and performance. Our analysis provides a case study of the lock-in of an institution that we believe, for reasons similar to North's, to be inimical to the healthy development of a market economy in Russia. In such a case, it would be truly paradoxical if the Russian government's attempt to balance the budget was the spark that ignited the wage arrears explosion in the first place.

\section{Conclusion}

This paper has developed and tested some key features of a model of neighborhood effects in employer decisions to violate wage contracts. Our simple model provides a framework for understanding how neighborhood effects may arise through the relationship between the costs to employers of using arrears and the extent of arrears in the local labor market environment. It also provides some guidance for empirical estimation of the reaction function and of the feedback loops that may support a timely or late wage payment practice. Under certain circumstances, the model also suggests the possibility of multiple equilibria, and, assuming a particular functional form for the manager's costs of wage arrears, we have derived an estimable nonlinear reaction function.

Our empirical analysis provides strong evidence of positive feedback in the manager's choice of wage arrears from the behavior of other firms operating in the same local labor market. Rational managers do indeed appear to take into account the wage arrears behavior of neighboring employers when choosing their own strategies. This result for the non-public sector of the Russian economy is robust to the inclusion of fixed effects at the level of the worker, the firm, and the local labor market, and to the use of an instrumental variable associated with the exogenous determination of arrears in the public sector.

Furthermore, the data provide strong support for the model's key assumptions, including the existence of several feedback loops. We find that higher wage arrears in the local labor market attenuate the positive impact of arrears on the worker's quit probability and the firm's quit rate. Higher local arrears also reduce the negative impact of a worker's arrears on measures of his/her effort and work hours. They reduce the positive impact of arrears on the strike probability, and they reduce the impact of the level of a firm's arrears on the probability that a legal penalty will be assessed. The data imply that wage rates can be treated as exogenous to the determination of wage arrears, which makes conceptual sense in light of the timing of these decisions (annual or bi-annual in the case of wage rates, monthly in the case of arrears) and the 
impossibility of contracting on arrears, since this would imply a contract to violate a contract. The data are also consistent with our hypothesis that the reverse feedback from the non-public to the public sector is quite weak.

The final set of empirical results concern the nonlinear reaction function and the possibility of multiple equilibria in wage arrears. Our estimates of a cubic reaction function, derived from a particular functional form for the costs of arrears, imply a clear S-shape. The magnitudes of the parameters imply that the average Russian region may indeed face multiple equilibria. The estimates imply a threshold equilibrium of about 4 monthly wages and a late payment equilibrium of 9.5. We hasten to add that these results are merely illustrative of the method that can be used for addressing this issue, but we believe they go a considerable distance toward demonstrating the existence of multiple equilibria in the peculiar institution of wage arrears.

Our analysis and results contribute not only to understanding the peculiar phenomenon of wage arrears but also to several distinct areas of economic research. Studies of the historical foundations of successful modern economies have emphasized the importance of contract enforcement institutions and property rights (Greif, 1993; Greif, Milgrom, and Weingast, 1994; Milgrom, North, and Weingast, 1990; North, 1990). While providing explanations for the function and origins of such institutions as the merchant guild and the law merchant, however, the literature has paid less attention to institutional arrangements when contracts are not enforced and to the mechanisms that may lead such arrangements, even if inferior, to be self-sustaining. A second strand of literature is concerned directly with coordination failures, particularly in developing economies, where the possibility of an "underdevelopment trap" due to investment spillovers has been studied by Rosenstein-Rodan (1943) and Murphy, Shleifer, and Vishny (1989), and extended to human capital investment by Azariadis and Drazen (1990); Hoff (2000) contains an overview. This research, however, does not consider the breakdown of contract enforcement as a possible case of coordination failure, as we do in this paper.

The broad notion that spillovers create positive feedback and possibly multiple equilibria in outcomes appears in a number of fields. For instance, externalities may help to explain persistent regional variation in crime rates, whether due to legal congestion (Sah, 1991) or social interactions and learning (Glaeser, Sacerdote, and Scheinkman, 1996). Network externalities may create multiple equilibria and path dependence in technology adoption (David, 1985; Katz 
and Shapiro, 1986; Arthur, 1989). Spillovers in investment, market participation, or technology may produce the possibility of multiple levels of equilibrium aggregate output and employment (Cooper and John, 1988; Kiyotaki, 1988; Chamley, 1999). Some efficiency wage models (e.g., Stiglitz, 1985) also rely on an externality for other firms when an employer chooses to pay a wage premium either to lower quits or to increase effort, and it has been argued that employers' layoff and training decisions and employee investments in training contain similar externalities (Levine and Parkin, 1994; Acemoglu, 1997). The general class of games with strategic complementarities has been extensively analyzed by Milgrom and Roberts (1990), among others, while the essays in Blume and Durlauf (2001) consider a variety of issues in the area of social dynamics.

In all of these examples, a broadly similar interaction mechanism works to promote convergent practices, and, depending on parameters, the positive feedback may generate multiple equilibria. Empirical analyses of the phenomena are relatively few, however, perhaps because appropriate data are frequently not available, because testing has been hampered by difficult identification problems, and because it is usually difficult to observe feedback mechanisms. In this paper, we have addressed these problems using rich panel data that permit us to control for correlated effects that typically confound inferences in interactions-based models, and we have exploited a useful instrumental variable arising from an exogenous policy intervention. We have also been able to measure several mechanisms that may function as feedback loops supporting multiple equilibria in the institution of timeliness of wage payment.

Finally, the paper contributes to the literature on the role of institutional change in economic development and in the transition from socialism. A major theme in the literature is the importance of new institutions that should be created for markets to function well (e.g., Murrell, 1992; Dewatripont and Roland, 1996; Greif and Kandel, 1995), but less attention has been paid to the possibility of the evolution of institutions that not only fail to support the functioning of markets but actually serve to undermine them. Although a complete welfare analysis is beyond the scope of the paper, we have argued that pervasive wage arrears practices have perverse consequences for the development of enforceable contracts and secure property rights, arguably among the most important institutions of a market economy. 


\section{References}

Acemoglu, Daron, “Training and Innovation in an Imperfect Labor Market.” Review of Economic Studies, 64: 445-464, July 1997.

Akerlof, George A., "Labor Contracts as Partial Gift Exchange." Quarterly Journal of Economics, 97: 543-569, 1982.

Andrienko, Yury, and Sergei Guriev, "Determinants of Interregional Mobility in Russia: Evidence from Panel Data.” Economics of Transition, 12(1): 1-27, 2004.

Arthur, Brian W., "Competing Technologies, Increasing Returns, and Lock-in by Historical Events.” Economic Journal, 99: 116-131, 1989.

Aslund, Anders, "Social Problems and Policy in Postcommunist Russia," in Ethan B. Kapstein and Michael Mandelbaum, eds., Sustaining the Transition: The Social Safety Net in Postcommunist Europe. New York: Council on Foreign Relations, 1997.

Azariadis, Costas, and Allan Drazen, “Threshold Externalities in Economic Development." Quarterly Journal of Economics, 105(2): 501-526, May 1990.

Blume, Lawrence E., and Steven N. Durlauf, "The Interactions-Based Approach to Socioeconomic Behavior,” in Steven N. Durlauf and H. Peyton Young, eds., Social Dynamics, pp. 15-44. Washington, DC: Brookings Institution Press, 2001.

Brock, William A., and Steven N. Durlauf, "Interactions-Based Models," in James J. Heckman and Edward Leamer, eds., Handbook of Econometrics, Vol. 5, pp. 3297-3380. Elsevier Science, 2001.

Brown, J. David, and John S. Earle, “The Reallocation of Workers and Jobs in Russian Industry: New Evidence on Measures and Determinants.” Economics of Transition, 11(2): 221-252, June 2003.

Chamley, Christophe, “Coordinating Regime Switches.” Quarterly Journal of Economics, 114: 869-905, August 1999.

Cooper, Russell, and Andrew John, “Coordinating Failures in Keynesian Models.” Quarterly Journal of Economics, 103: 441-463, August 1988.

David, Paul A., “Clio and the Economics of QWERTY.” American Economic Review, 75: 332337, 1985.

Desai, Padma, and Todd Idson, Work without Wages: Russia's Nonpayment Crisis. Cambridge, MA: MIT Press, 2000.

Dewatripont, Mathias, and Gerard Roland, "Transition as a Process of Large-Scale Institutional Change.” Economics of Transition, 4: 1-30, 1996.

Earle, John S., and Klara Sabirianova, "How Late to Pay? Understanding Wage Arrears in Russia.” Journal of Labor Economics, 20: 661-707, 2002.

Evans, William N., Wallace E. Oates, and Robert M. Schwab, "Measuring Peer Group Effects: A Study of Teenage Behavior.” Journal of Political Economy, 100(5): 966-991, October 1992. 
Freeman, Richard B., "The Exit-Voice Tradeoff in the Labor Market: Unionism, Job Tenure, Quits, and Separations.” Quarterly Journal of Economics, 94(4): 643-674, 1980.

Friebel, Guido, and Sergei Guriev, "Should I Stay or Can I Go: Attaching Workers Through InKind Payments.” Working paper, New Economic School, Moscow, 2002.

Gimpelson, Vladimir, "The Politics of Labour Market Adjustment: The Case of Russia." Collegium Budapest (Budapest) Discussion Paper No. 54, November 1998.

Gimpelson, Vladimir, and Douglas Lippoldt, The Russian Labor Market: Between Transition and Turmoil. Lanham, MD/Oxford, UK: Rowman and Littlefield, 2001.

Glaeser, Edward, Bruce Sacerdote, and Jose A. Scheinkman, “Crime and Social Interactions.” Quarterly Journal of Economics, 111: 507-548, 1996.

Goskomstat, Overdue Wage Payments on January 1, 1999 (Statistical Bulletin). Moscow: Goskomstat of Russia, 1999.

Greif, Avner, “Contract Enforceability and Economic Institutions in Early Trade: The Maghribi Traders’ Coalition.” American Economic Review, 83(3): 525-548, June 1993.

Greif, Avner, and Eugene Kandel, "Contract Enforcement Institutions: Historical Perspective and Current Status in Russia," in Edward Lazear, ed., Economic Transition in Eastern Europe and Russia: Realities of Reform. Stanford: Hoover Institution Press, 1995.

Greif, Avner, Paul Milgrom, and Barry R. Weingast, "Coordination, Commitment, and Enforcement: The Case of the Merchant Guild.” Journal of Political Economy, 102(4): 745776, August 1994.

Heleniak, Timothy, “Internal Migration in Russia During the Economic Transition.” Post-Soviet Geography and Economics, 38(2): 81-104, February 1997.

Hoff, Karla, "Beyond Rosenstein-Rodan: The Modern Theory of Underdevelopment Traps." Proceedings of the World Bank Annual Conference on Development Economics 2000 (forthcoming).

Institute for the Economy in Transition, Russian Economy in 1993: Trends and Prospects. Moscow: Institute for the Economy in Transition, 1994.

Javeline, Deborah, Protest and the Politics of Blame: The Russian Response to Unpaid Wages. Ann Arbor: The University of Michigan Press, 2003.

Katz, Michael, and Carl Shapiro, "Technology Adoption in the Presence of Network Externalities.” Journal of Political Economy, 94: 822-841, 1986.

Kennan, John, “The Economics of Strikes,” in Orley Ashenfelter and Richard Layard, eds., Handbook of Labor Economics. Amsterdam: Elsevier Science Publishers, 1986.

Kiyotaki, Nobuhiro, "Multiple Expectational Equilibria under Monopolistic Competition." Quarterly Journal of Economics, 103: 695-713, November 1988.

Layard, Richard, and Andrea Richter, "How Much Unemployment is Needed for Restructuring: The Russian Experience.” Economics of Transition, 3: 35-58, 1995.

Lee, Kevin C., and M. Hashem Pesaran, "The Role of Sectoral Interactions in Wage Determination in the UK Economy.” Economic Journal, 103(416): 21-55, January 1993. 
Lehmann, Hartmut, Jonathan Wadsworth, and Alessandro Acquisti, “Grime and Punishment: Job Insecurity and Wage Arrears in the Russian Federation.” Journal of Comparative Economics, 27: 595-617, 1999.

Levine, David I., and Richard J. Parkin, "Work Organization, Employment Security, and Macroeconomic Stability.” Journal of Economic Behavior and Organization, 24(3): 251-271, August 1994.

Levinson, Harold M., "Pattern Bargaining: A Case Study of the Automobile Workers." Quarterly Journal of Economics, 74(2): 296-317, May 1960.

Malcomson, James M., “Contracts, Hold-Up, and Labor Markets.” Journal of Economic Literature, 35(4): 1916-1957, 1997.

Manski, Charles F., "Identification of Endogenous Social Effects: The Reflection Problem.” Review of Economic Studies, 60: 531-542, 1993.

Milgrom, Paul R., Douglass North, and Barry R. Weingast, "The Role of Institutions in the Revival of Trade: The Medieval Law Merchant, Private Judges, and the Champagne Fairs.” Economics and Politics, 1: 1-23, 1990.

Milgrom, Paul, and John Roberts, "Rationalizability, Learning, and Equilibrium in Games with Strategic Complementarities.” Econometrica, 57(6): 1255-1277, November 1990.

Mitchneck, Beth, and David A. Plane, "Migration and the Quasi-Labor Market in Russia." International Regional Science Review, 18(3): 267-288, 1995.

Moffitt, Robert A., "Policy Interventions, Low-Level Equilibria, and Social Interactions," in Steven N. Durlauf and H. Peyton Young, eds., Social Dynamics, pp. 45-82. Washington, D.C.: Brookings Institution Press, 2001.

Murphy, Kevin M., Andrei Shleifer, and Robert W. Vishny, "Industrialization and the Big Push.” Journal of Political Economy, 97(5): 1003-1026, October 1989.

Murrell, Peter, "Evolution in Economics and in the Economic Reform of the Centrally Planned Economies," in C.C. Clague and G. Rausser, eds., The Emergence of Market Economies in Eastern Europe, pp. 35-53. Cambridge, MA and Oxford: Blackwell, 1992.

North, Douglass C., Institutions, Institutional Change, and Economic Performance. New York: Cambridge University Press, 1990.

OECD Economic Surveys 1997-1998: The Russian Federation. Paris: OECD, 1997.

Oi, Walter Y., “Labor as a Quasi-Fixed Factor.” Journal of Political Economy, 70(6): 538-555, 1962.

Radio Free Europe/Radio Liberty Newsline, "Wage Arrears Swell.” Vol. 8(81), pt. 2, April 30, 2004.

Rosen, Sherwin, “Hedonic Prices and Implicit Markets.” Journal of Political Economy, 82: 3455, 1974.

Rosenstein-Rodan, Paul, "Problems of Industrialization of Eastern and Southeastern Europe." Economic Journal, 53: 202-211, June-September 1943. 
Sah, Raaj K., "Social Osmosis and Patterns of Crime.” Journal of Political Economy, 99: 12721295, 1991.

Shapiro, Carl, and Joseph E. Stiglitz, "Equilibrium Unemployment as a Worker Discipline Device.” American Economic Review, 74: 433-444, 1984.

Stiglitz, Joseph E., “Alternative Theories of Wage Determination and Unemployment in LDCs: The Labor Turnover Model.” Quarterly Journal of Economics, 88: 194-227, 1974.

—_, “Equilibrium Wage Distributions.” Economic Journal, 95: 595-618, September 1985.

Swafford, Michael, et al., "Sample of the Russian Federation Rounds V, VI, and VII of the Russian Longitudinal Monitoring Survey.” Technical Report, 1997. 


\section{Appendix.}

To check the three equilibria in Section 6.2 for stability, we may calculate the slope of the reaction function at the equilibrium points. Stable equilibria should have a reaction function slope less than one:

$$
\left.\frac{\partial \varpi}{\partial \Omega}\right|_{\omega^{*}}=\frac{b+2 c \omega^{*}-3 d \omega^{*^{2}}}{2 a}<1,
$$

which implies

$$
b-2 a+2 c \omega^{*}-3 d \omega^{*^{2}}<0 .
$$

We may check this condition for each equilibrium in turn. $\omega_{1}^{*}$ is clearly stable:

$$
\left.\frac{\partial \varpi}{\partial \Omega}\right|_{\omega_{1}^{*}}=\frac{b}{2 a}<1
$$

The second equilibrium is unstable: $\left.\frac{\partial \varpi}{\partial \Omega}\right|_{\omega_{2}{ }^{*}}>1$, since upon substitution of $\omega_{2}{ }^{*}$ into (A1) we obtain

$$
\begin{gathered}
b-2 a+2 c\left(\frac{c-\sqrt{c^{2}+4 d(b-2 a)}}{2 d}\right)-3 d\left(\frac{c-\sqrt{c^{2}+4 d(b-2 a)}}{2 d}\right)^{2} \\
=\frac{\left(\sqrt{c^{2}+4 d(b-2 a)}\right)\left(c-\sqrt{c^{2}+4 d(b-2 a)}\right)}{2 d}>0
\end{gathered}
$$

Finally, the third equilibrium is stable: $\left.\frac{\partial \varpi}{\partial \Omega}\right|_{\omega_{3} *}<1$ as

$$
\begin{gathered}
b-2 a+2 c\left(\frac{c+\sqrt{c^{2}+4 d(b-2 a)}}{2 d}\right)-3 d\left(\frac{c+\sqrt{c^{2}+4 d(b-2 a)}}{2 d}\right)^{2} \\
=\frac{\left(\sqrt{c^{2}+4 d(b-2 a)}\right)\left(-c-\sqrt{c^{2}+4 d(b-2 a)}\right)}{2 d}<0
\end{gathered}
$$

Thus, we have found three equilibria and showed that two of them are stable and one is not stable. Figure 2 shows the symmetric Nash equilibria and the dynamics implied by the model. In the range where $\omega_{1}{ }^{*}<\Omega<\omega_{2}{ }^{*}$, a self-interested manager will choose $\omega<\Omega$, so optimizing behavior by all managers will tend to drive down $\Omega$. Beyond $\omega_{2}{ }^{*}$, managerial behavior will tend to push up $\Omega$ until it reaches $\omega_{3}{ }^{*}$, the stable late payment equilibrium. 
Table 1: Magnitude of Wage Arrears, Worker Data

\begin{tabular}{|c|c|c|c|c|c|}
\hline & 1994 & 1995 & 1996 & 1998 & 2000 \\
\hline$E\left(\omega_{\mathrm{t}}\right)$ & 1.10 & 1.11 & 1.92 & 3.00 & 1.14 \\
\hline$E\left(\omega_{\mathrm{t}} \mid \omega_{\mathrm{t}}>0\right)$ & 2.75 & 2.73 & 3.27 & 4.82 & 4.24 \\
\hline \multicolumn{6}{|l|}{ Unconditional Distribution $\left(\omega_{\mathrm{t}}\right)$} \\
\hline$\omega_{\mathrm{t}}=0$ month & 0.603 & 0.593 & 0.415 & 0.379 & 0.731 \\
\hline$=1$ month & 0.149 & 0.156 & 0.149 & 0.122 & 0.111 \\
\hline$=2-3$ months & 0.164 & 0.170 & 0.250 & 0.219 & 0.085 \\
\hline$=4-6$ months & 0.055 & 0.055 & 0.134 & 0.163 & 0.032 \\
\hline$=7-9$ months & 0.014 & 0.007 & 0.025 & 0.046 & 0.007 \\
\hline$>9$ months & 0.016 & 0.019 & 0.028 & 0.072 & 0.034 \\
\hline \multicolumn{6}{|l|}{$E\left(\Omega_{\mathrm{t}}\right)$ in Selected Districts } \\
\hline “A” & 0.417 & 0.478 & 1.167 & 1.080 & 0.407 \\
\hline “B” & 0.627 & 0.480 & 0.593 & 1.256 & 0.137 \\
\hline “C” & 2.236 & 2.274 & 3.574 & 4.301 & 1.408 \\
\hline “D” & 4.119 & 6.581 & 6.175 & 11.690 & 9.898 \\
\hline $\mathrm{N}$ & 4667 & 4310 & 4050 & 3781 & 4000 \\
\hline
\end{tabular}

Notes: $\omega \mathrm{t}=$ number of monthly wages reported overdue by an employee-respondent in year $t ; \Omega \mathrm{t}=$ average number of monthly wages owed in the rest of the firm's local labor market. Sample consists of all employee-respondents in the RLMS. Districts are indicated as "A" through " $D$ " because the RLMS data confidentiality agreement precludes the release of district names. 
Table 2: Characteristics of the Worker Sample

\begin{tabular}{lc|lc}
\hline \multicolumn{1}{c|}{ Variable } & Mean & \multicolumn{1}{c}{ Variable } & Mean \\
\hline Male & 0.473 & Hourly Wage Rate (rubles) & 12.094 \\
Schooling (years) & 11.851 & & $(20.033)$ \\
& $(2.524)$ & Family Income (thous.rubles) & 0.961 \\
Age (years) & 39.024 & & $(1.775)$ \\
& $(11.800)$ & Industry & \\
Tenure (years) & 8.180 & Mining & 0.023 \\
& $(9.068)$ & Machine Building & 0.109 \\
Employee Owns & & Light and Food & 0.049 \\
No shares & 0.813 & Other Manufacturing & 0.102 \\
$<1 \%$ & 0.105 & Agriculture/Forestry & 0.101 \\
$\geq 1 \%$ & 0.036 & Transportation & 0.077 \\
No information & 0.046 & Construction & 0.071 \\
Occupation & & Private Services & 0.140 \\
Managers & 0.039 & Public Services & 0.329 \\
Professionals & 0.155 & & \\
Technicians & 0.177 & Public Sector & 0.367 \\
Clerks & 0.072 & $\Omega_{\text {t }}$ (local arrears) & 1.612 \\
Service Workers & 0.096 & Monthly Hours of Work & $(1.472)$ \\
Craft Workers & 0.175 & Mesire & 147.804 \\
Operators and Assemblers & 0.179 & & $(73.686)$ \\
Unskilled Workers & 0.094 & Desire Switch Jobs & 0.383 \\
Army & 0.013 & Quit in Two Years & 0.291 \\
\hline
\end{tabular}

Notes: $\mathrm{N}=19316$, except for hours $(\mathrm{N}=18556)$, desire to switch jobs $(\mathrm{N}=18812)$, and quits $(\mathrm{N}=9119)$. Sample consists of all employee-respondents with non-missing values on wage arrears, schooling, age, tenure, occupation, and industry. Standard deviations are shown in parentheses. 
Table 3: Characteristics of the Firm Sample

\begin{tabular}{lc|lc}
\hline \multicolumn{1}{c}{ Variable } & Mean & \multicolumn{1}{c}{ Variable } & Mean \\
\hline$\omega_{\mathrm{t}}$ (number of monthly & 1.175 & Industry & \\
wages overdue) & $(2.375)$ & Energy \& Fuel & 0.088 \\
$\Omega_{\mathrm{t}}$ (local arrears) & 1.146 & Metallurgy \& Chemicals & 0.081 \\
& $(1.321)$ & Machine Building & 0.318 \\
Strikes (dummy) & 0.019 & Wood and Building Materials & 0.105 \\
Quit Rate (quits/employment) & 0.169 & Light & 0.089 \\
& $(0.169)$ & Food & 0.135 \\
Legal Penalties (dummy) & 0.010 & Other & 0.060 \\
Union Density (\% members) & & Agriculture & 0.123 \\
$0-9 \%$ & 0.086 & Type of Location & \\
$10-59 \%$ & 0.095 & Moscow and St. Petersburg & 0.105 \\
60-79\% & 0.088 & Regional Capital City & 0.360 \\
80-89\% & 0.087 & Other City & 0.342 \\
90-99\% & 0.275 & Non-City & 0.194 \\
$100 \%$ & 0.369 & Legal Environment & \\
Firm Fringe Benefits & & Fraction of cases when managers & 0.098 \\
Training & 0.647 & failed to pay assessed fines on time & $(0.085)$ \\
Kindergartens & 0.433 & Fraction of cases when arrears were & 0.216 \\
Housing & 0.382 & paid off after violation was & $(0.158)$ \\
Training Costs (days) /100 & 82.022 & discovered & \\
& $(92.850)$ & & \\
\hline
\end{tabular}

Notes: $\mathrm{N}=4061$, except for quit rate $(\mathrm{N}=2611)$ and legal penalties $(\mathrm{N}=3675)$. Sample consists of industrial and agricultural firms with non-missing values on wage arrears, union density, and fringe benefits in 1991-1999. Standard deviations are shown in parentheses. The quit rate is ratio of number quitting to average employment. 
Table 4: Estimates of the Linear Reaction Function, Non-Public Sector

\begin{tabular}{|c|c|c|c|c|c|}
\hline & OLS & IV/2SLS & $\begin{array}{c}\text { IV/2SLS, } \\
\text { District FE }\end{array}$ & $\begin{array}{l}\text { IV/2SLS, } \\
\text { Firm FE }\end{array}$ & $\begin{array}{c}\text { IV/2SLS, } \\
\text { Worker FE }\end{array}$ \\
\hline$\Omega_{\mathrm{t}}$ (local arrears) & $\begin{array}{l}0.894 * * * \\
(0.088)\end{array}$ & $\begin{array}{l}0.905^{* * *} \\
(0.071)\end{array}$ & $\begin{array}{l}0.777 * * * \\
(0.142)\end{array}$ & $\begin{array}{l}1.030 * * * \\
(0.105)\end{array}$ & $\begin{array}{c}0.991 * * * \\
(0.095)\end{array}$ \\
\hline Male & $\begin{array}{l}0.358^{* * *} \\
(0.111)\end{array}$ & $\begin{array}{l}0.357 * * * \\
(0.111)\end{array}$ & $\begin{array}{l}0.348^{* * *} \\
(0.110)\end{array}$ & $\begin{array}{l}0.360^{* * *} \\
(0.106)\end{array}$ & $\ldots$ \\
\hline Schooling (years) & $\begin{array}{c}0.002 \\
(0.021)\end{array}$ & $\begin{array}{c}0.003 \\
(0.021)\end{array}$ & $\begin{array}{l}-0.005 \\
(0.021)\end{array}$ & $\begin{array}{l}-0.015 \\
(0.022)\end{array}$ & $\begin{array}{l}-0.063 * \\
(0.036)\end{array}$ \\
\hline Age (years) & $\begin{array}{c}0.001 \\
(0.003)\end{array}$ & $\begin{array}{c}0.001 \\
(0.003)\end{array}$ & $\begin{array}{l}-0.000 \\
(0.003)\end{array}$ & $\begin{array}{l}0.010^{* *} \\
(0.005)\end{array}$ & $\cdots$ \\
\hline Tenure (years) & $\begin{array}{l}0.026 * * * \\
(0.005)\end{array}$ & $\begin{array}{l}0.026 * * * \\
(0.005)\end{array}$ & $\begin{array}{l}0.028 * * * \\
(0.005)\end{array}$ & $\begin{array}{l}0.020^{* * *} \\
(0.005)\end{array}$ & $\begin{array}{l}0.037^{* * *} \\
(0.007)\end{array}$ \\
\hline Hourly Wage Rate (rubles) & $\begin{array}{l}-0.003^{* *} \\
(0.001)\end{array}$ & $\begin{array}{l}-0.003^{* *} \\
(0.001)\end{array}$ & $\begin{array}{l}-0.005^{* * * *} \\
(0.002)\end{array}$ & $\begin{array}{l}-0.003 \\
(0.002)\end{array}$ & $\begin{array}{l}-0.003 \\
(0.002)\end{array}$ \\
\hline Family Income (thous.rubles) & $\begin{array}{l}-0.012 \\
(0.016)\end{array}$ & $\begin{array}{l}-0.011 \\
(0.015)\end{array}$ & $\begin{array}{l}-0.028 * * \\
(0.013)\end{array}$ & $\begin{array}{l}-0.008 \\
(0.024)\end{array}$ & $\begin{array}{l}-0.015 \\
(0.023)\end{array}$ \\
\hline Employee Owns (omitted: No & & & & & \\
\hline$<1 \%$ & $\begin{array}{l}0.252^{* *} \\
(0.094)\end{array}$ & $\begin{array}{l}0.252^{* * *} \\
(0.094)\end{array}$ & $\begin{array}{l}0.292^{* * *} \\
(0.089)\end{array}$ & $\begin{array}{c}0.187^{*} \\
(0.113)\end{array}$ & $\begin{array}{l}0.330^{* * *} \\
(0.120)\end{array}$ \\
\hline$\geq 1 \%$ & $\begin{array}{c}0.168 \\
(0.167)\end{array}$ & $\begin{array}{c}0.166 \\
(0.164)\end{array}$ & $\begin{array}{c}0.157 \\
(0.144)\end{array}$ & $\begin{array}{c}0.113 \\
(0.188)\end{array}$ & $\begin{array}{l}0.299 * \\
(0.182)\end{array}$ \\
\hline No information & $\begin{array}{c}0.274 \\
(0.221)\end{array}$ & $\begin{array}{c}0.274 \\
(0.216)\end{array}$ & $\begin{array}{c}0.306 \\
(0.207)\end{array}$ & $\begin{array}{l}0.342^{* *} \\
(0.146)\end{array}$ & $\begin{array}{l}0.384^{* *} \\
(0.151)\end{array}$ \\
\hline Year 1995 & $\begin{array}{c}0.007 \\
(0.058)\end{array}$ & $\begin{array}{c}0.007 \\
(0.058)\end{array}$ & $\begin{array}{c}0.008 \\
(0.061)\end{array}$ & $\begin{array}{c}0.029 \\
(0.100)\end{array}$ & $\begin{array}{c}0.022 \\
(0.088)\end{array}$ \\
\hline Year 1996 & $\begin{array}{c}0.082 \\
(0.087)\end{array}$ & $\begin{array}{c}0.073 \\
(0.073)\end{array}$ & $\begin{array}{c}0.198 \\
(0.133)\end{array}$ & $\begin{array}{c}0.168 \\
(0.140)\end{array}$ & $\begin{array}{c}0.178 \\
(0.123)\end{array}$ \\
\hline Year 1998 & $\begin{array}{c}0.250 \\
(0.178)\end{array}$ & $\begin{array}{c}0.229 * \\
(0.126)\end{array}$ & $\begin{array}{c}0.495^{*} \\
(0.266)\end{array}$ & $\begin{array}{c}0.350 \\
(0.240)\end{array}$ & $\begin{array}{c}0.189 \\
(0.208)\end{array}$ \\
\hline Year 2000 & $\begin{array}{c}0.119 \\
(0.131)\end{array}$ & $\begin{array}{c}0.118 \\
(0.129)\end{array}$ & $\begin{array}{c}0.151 \\
(0.145)\end{array}$ & $\begin{array}{l}0.437 * * * \\
(0.111)\end{array}$ & $\begin{array}{l}0.293^{* * *} \\
(0.102)\end{array}$ \\
\hline Intercept & $\begin{array}{l}-1.118^{* *} \\
(0.522)\end{array}$ & $\begin{array}{l}-1.133^{* *} \\
(0.510)\end{array}$ & $\begin{array}{l}-0.873 * * \\
(0.398)\end{array}$ & $\begin{array}{l}-1.246^{* *} \\
(0.551)\end{array}$ & $\begin{array}{l}-0.648 \\
(0.492)\end{array}$ \\
\hline $\mathrm{R}^{2}$ overall & 0.241 & 0.241 & 0.260 & 0.160 & 0.231 \\
\hline $\begin{array}{l}\mathrm{n}^{\mathrm{b}} \Omega^{\mathrm{b}}{ }_{\mathrm{t}} \text { (weighted local arrears } \\
\text { in the public sector) }\end{array}$ & $\ldots$ & $\begin{array}{l}\text { First Stage R } \\
2.110^{* * *} \\
(0.032)\end{array}$ & $\begin{array}{c}\text { ults for Excluc } \\
1.631^{* * * *} \\
(0.024)\end{array}$ & $\begin{array}{c}\text { ed Instrume } \\
1.685^{* * *} \\
(0.029)\end{array}$ & $\begin{array}{l}1.658 * * * \\
(0.031)\end{array}$ \\
\hline $\begin{array}{l}\mathrm{R}^{2} \text { first stage } \\
\text { F-test of excluded instruments }\end{array}$ & $\begin{array}{l}\cdots \\
\ldots\end{array}$ & $\begin{array}{l}0.512 \\
4247.45\end{array}$ & $\begin{array}{c}0.882 \\
4687.06\end{array}$ & $\begin{array}{l}0.389 \\
3289.40\end{array}$ & $\begin{array}{c}0.397 \\
2786.99\end{array}$ \\
\hline
\end{tabular}

Notes: N=12306 employee-respondents in the non-public sector. Robust standard errors are in parentheses; *-significant at $10 \%$; **-significant at 5\%; ***-significant at $1 \%$. Standard errors in columns 1 through 3 are adjusted for clustering on district. 9 occupation dummies, 9 industry dummies, and 2 dummies for missing values of wages and family income are included but not shown here. 
Table 5: Costs of Wage Arrears, Results from Worker Data

\begin{tabular}{|c|c|c|c|}
\hline & $\begin{array}{c}\text { Quit in } \\
\text { Two Years } \\
\text { (Probit, dF/dX) }\end{array}$ & $\begin{array}{c}\text { Desire to } \\
\text { Switch Jobs } \\
\text { (Probit, dF/dX) } \\
\end{array}$ & $\begin{array}{c}\text { Hours of Work } \\
\text { (Tobit) }\end{array}$ \\
\hline$\omega_{\mathrm{t}}$ (number of monthly wages overdue) & $\begin{array}{c}0.009 * * * \\
(0.003)\end{array}$ & $\begin{array}{c}0.024 * * * \\
(0.002)\end{array}$ & $\begin{array}{l}-1.463^{* * *} \\
(0.260)\end{array}$ \\
\hline$\Omega_{\mathrm{t}}($ local arrears $)$ & $\begin{array}{l}-0.002 \\
(0.009)\end{array}$ & $\begin{array}{l}0.000 \\
(0.006)\end{array}$ & $\begin{array}{l}-0.741 \\
(0.891)\end{array}$ \\
\hline$\omega_{\mathrm{t}} * \Omega_{\mathrm{t}}$ & $\begin{array}{l}-0.001 * \\
(0.001)\end{array}$ & $\begin{array}{l}-0.002^{* * *} \\
(0.000)\end{array}$ & $\begin{array}{l}0.170 * * * \\
(0.052)\end{array}$ \\
\hline Male & $\begin{array}{l}0.060^{* * *} \\
(0.012)\end{array}$ & $\begin{array}{l}-0.028 * * * \\
(0.009)\end{array}$ & $\begin{array}{l}29.076 * * * \\
(1.231)\end{array}$ \\
\hline Schooling (years) & $\begin{array}{l}-0.011^{* * *} \\
(0.003)\end{array}$ & $\begin{array}{l}0.010 * * * \\
(0.002)\end{array}$ & $\begin{array}{l}0.546 * * \\
(0.272)\end{array}$ \\
\hline Age (years) & $\begin{array}{l}0.002 * * * \\
(0.000)\end{array}$ & $\begin{array}{l}-0.008^{* * *} \\
(0.000)\end{array}$ & $\begin{array}{l}0.275^{* * *} \\
(0.050)\end{array}$ \\
\hline Tenure (years) & $\begin{array}{l}-0.007 * * * \\
(0.001)\end{array}$ & $\begin{array}{l}-0.008 * * * \\
(0.001)\end{array}$ & $\begin{array}{l}-0.300 * * * \\
(0.066)\end{array}$ \\
\hline Hourly Wage Rate (rubles)/10 & $\begin{array}{l}-0.002 \\
(0.003)\end{array}$ & $\begin{array}{l}-0.016 * * * \\
(0.003)\end{array}$ & $\begin{array}{l}-7.314^{* * *} \\
(0.273)\end{array}$ \\
\hline Family Income (thous.rubles)/100 & $\begin{array}{c}0.124 \\
(0.338)\end{array}$ & $\begin{array}{l}-0.337 \\
(0.242)\end{array}$ & $\begin{array}{l}-95.093 * * * \\
(30.512)\end{array}$ \\
\hline Employee Owns (omitted: No Shares) & & & \\
\hline$<1 \%$ & $\begin{array}{l}-0.042^{* * *} \\
(0.016)\end{array}$ & $\begin{array}{c}0.006 \\
(0.013)\end{array}$ & $\begin{array}{c}0.313 \\
(1.784)\end{array}$ \\
\hline$\geq 1 \%$ & $\begin{array}{l}-0.004 \\
(0.026)\end{array}$ & $\begin{array}{l}-0.085^{* * *} \\
(0.019)\end{array}$ & $\begin{array}{l}19.771 * * * \\
(2.784)\end{array}$ \\
\hline No information & $\begin{array}{l}-0.050 * * \\
(0.021)\end{array}$ & $\begin{array}{l}-0.031^{*} \\
(0.018)\end{array}$ & $\begin{array}{l}-2.195 \\
(2.518)\end{array}$ \\
\hline Year 1995 & $\ldots$ & $\begin{array}{l}-0.011 \\
(0.011)\end{array}$ & $\begin{array}{l}6.748 * * * \\
(1.538)\end{array}$ \\
\hline Year 1996 & $\begin{array}{l}-0.004 \\
(0.014)\end{array}$ & $\begin{array}{l}-0.021 \\
(0.013)\end{array}$ & $\begin{array}{l}10.287^{* * *} \\
(1.742)\end{array}$ \\
\hline Year 1998 & $\begin{array}{l}-0.003 \\
(0.020)\end{array}$ & $\begin{array}{l}-0.048 * * * \\
(0.016)\end{array}$ & $\begin{array}{c}-13.217 * * * \\
(2.309)\end{array}$ \\
\hline Year 2000 & $\ldots$ & $\begin{array}{l}-0.014 \\
(0.011)\end{array}$ & $\begin{array}{l}-7.937 * * * \\
(1.573)\end{array}$ \\
\hline Intercept & $\cdots$ & $\ldots$ & $\begin{array}{c}143.926 * * * \\
(5.124)\end{array}$ \\
\hline $\begin{array}{l}\mathrm{N} \\
\mathrm{LR} \text { chi }^{2} / \mathrm{Wald} \mathrm{chi}^{2} \\
\text { Pseudo } \mathrm{R}^{2}\end{array}$ & $\begin{array}{c}9119 \\
771.938 \\
0.077\end{array}$ & $\begin{array}{c}18812 \\
2038.743 \\
0.089\end{array}$ & $\begin{array}{c}18556 \\
7221.371 \\
0.036\end{array}$ \\
\hline
\end{tabular}

Notes: Sample consists of all employee-respondents in the RLMS. Robust standard errors in parentheses; *-significant at $10 \%$; **-significant at 5\%; ***-significant at 1\%. 9 occupation dummies, 9 industry dummies, 52 district dummies, and 2 dummies for missing values of wages and family income are included but not shown here. 
Table 6: Costs of Wage Arrears, Results from Firm Data

\begin{tabular}{|c|c|c|c|}
\hline & $\begin{array}{l}\text { Quit Rate } \\
\text { (OLS) }\end{array}$ & $\begin{array}{c}\text { Strikes } \\
\text { (Probit, dF/dX) }\end{array}$ & $\begin{array}{l}\text { Legal Penalties } \\
\text { (Probit, dF/dX) }\end{array}$ \\
\hline$\omega_{\mathrm{t}}$ (number of monthly wages & $0.010 * * *$ & $0.003 * * *$ & $0.0006 * *$ \\
\hline overdue) & $(0.002)$ & $(0.001)$ & $(0.0003)$ \\
\hline$\Omega_{\mathrm{t}}$ (local arrears) & -0.001 & $0.002 * *$ & 0.0004 \\
\hline & $(0.004)$ & $(0.001)$ & $(0.0003)$ \\
\hline$\omega_{\mathrm{t}} * \Omega_{\mathrm{t}}$ & $\begin{array}{l}-0.002 * * \\
(0.001)\end{array}$ & $\begin{array}{l}-0.001 * * * \\
(0.000)\end{array}$ & $\begin{array}{l}-0.0001 * * \\
(0.0001)\end{array}$ \\
\hline \multicolumn{4}{|l|}{ Union density ( $100 \%$ is omitted) } \\
\hline $0-9 \%$ & $\begin{array}{l}0.047 * * \\
(0.023)\end{array}$ & $\begin{array}{l}-0.001 \\
(0.003)\end{array}$ & $\cdots$ \\
\hline $10-59 \%$ & $\begin{array}{l}0.024 * * \\
(0.012)\end{array}$ & $\begin{array}{c}0.002 \\
(0.004)\end{array}$ & $\cdots$ \\
\hline $60-79 \%$ & $\begin{array}{l}-0.009 \\
(0.011)\end{array}$ & $\begin{array}{c}0.009 \\
(0.006)\end{array}$ & $\cdots$ \\
\hline $80-89 \%$ & $\begin{array}{l}-0.000 \\
(0.011)\end{array}$ & $\begin{array}{c}0.004 \\
(0.004)\end{array}$ & $\cdots$ \\
\hline $90-100 \%$ & $\begin{array}{c}0.002 \\
(0.006)\end{array}$ & $\begin{array}{c}0.000 \\
(0.003)\end{array}$ & $\cdots$ \\
\hline \multicolumn{4}{|l|}{ Fringe benefits provided by firms (dummies) } \\
\hline Training & $\begin{array}{l}-0.020 * * \\
(0.008)\end{array}$ & $\begin{array}{l}0.004 * * \\
(0.002)\end{array}$ & .. \\
\hline Kindergartens & $\begin{array}{l}-0.011 \\
(0.007)\end{array}$ & $\begin{array}{l}-0.001 \\
(0.002)\end{array}$ & $\cdots$ \\
\hline $\begin{array}{l}\text { Housing purchase and } \\
\text { construction }\end{array}$ & $\begin{array}{l}-0.009 \\
(0.006)\end{array}$ & $\begin{array}{c}0.003 \\
(0.002)\end{array}$ & $\cdots$ \\
\hline Training costs (days) /100 & $\begin{array}{l}-0.009 * * * \\
(0.003)\end{array}$ & $\begin{array}{l}0.002^{* * *} \\
(0.001)\end{array}$ & $\cdots$ \\
\hline \multicolumn{4}{|c|}{ Type of location (Moscow and St. Petersburg are omitted) } \\
\hline Regional Capital City & $\begin{array}{c}0.014 \\
(0.011)\end{array}$ & $\begin{array}{c}0.009 \\
(0.005)\end{array}$ & $\begin{array}{c}0.0001 \\
(0.0008)\end{array}$ \\
\hline Other City & $\begin{array}{l}0.026 * * \\
(0.011)\end{array}$ & $\begin{array}{c}0.004 \\
(0.005)\end{array}$ & $\begin{array}{l}-0.0021^{* *} \\
(0.0010)\end{array}$ \\
\hline Non-City & $\begin{array}{l}-0.028 * \\
(0.016)\end{array}$ & $\begin{array}{l}-0.004 \\
(0.004)\end{array}$ & $\begin{array}{l}-0.0016 * \\
(0.0008)\end{array}$ \\
\hline Legal Environment & & & \\
\hline $\begin{array}{l}\text { Fraction of cases when managers } \\
\text { failed to pay assessed fines on time } \\
\text { Fraction of cases when arrears } \\
\text { were paid off after violation was } \\
\text { discovered }\end{array}$ & $\cdots$ & $\cdots$ & $\begin{array}{l}-0.0091^{* *} \\
(0.0042) \\
-0.0057^{* *} \\
(0.0026)\end{array}$ \\
\hline $\begin{array}{l}\mathrm{N} \\
\mathrm{R}^{2} \\
\end{array}$ & $\begin{array}{l}2611 \\
0.137\end{array}$ & $\begin{array}{l}4061 \\
0.241 \\
\end{array}$ & $\begin{array}{l}3984 \\
0.303 \\
\end{array}$ \\
\hline
\end{tabular}

Notes: Sample consists of industrial and agricultural firms. Robust standard errors in parentheses; *-significant at $10 \%$; **-significant at 5\%; ***-significant at $1 \%$. Intercept and dummies for years, industries, and non-reported training costs are included but not shown here. 
Table 7: Testing Model Assumptions Hedonic Wage Function, Non-Public Sector

\begin{tabular}{|c|c|c|c|c|c|}
\hline & OLS & IV/2SLS & $\begin{array}{c}\text { IV/2SLS, } \\
\text { District FE }\end{array}$ & $\begin{array}{l}\text { IV/2SLS, } \\
\text { Firm FE }\end{array}$ & $\begin{array}{c}\text { IV/2SLS, } \\
\text { Worker FE }\end{array}$ \\
\hline$\omega_{t}$ (number of monthly & $-0.040^{* * *}$ & $-0.161^{* * *}$ & -0.022 & $-0.024^{* *}$ & $-0.032 * *$ \\
\hline wages overdue) & $(0.008)$ & $(0.052)$ & $(0.033)$ & $(0.010)$ & $(0.013)$ \\
\hline Male & $\begin{array}{l}0.346^{* * *} \\
(0.026)\end{array}$ & $\begin{array}{l}0.400^{* * *} \\
(0.031)\end{array}$ & $\begin{array}{l}0.367^{* * *} \\
(0.025)\end{array}$ & $\begin{array}{l}0.291 * * * \\
(0.021)\end{array}$ & $\ldots$ \\
\hline Schooling (years) & $\begin{array}{l}0.039 * * * \\
(0.007)\end{array}$ & $\begin{array}{l}0.034^{* * *} \\
(0.007)\end{array}$ & $\begin{array}{l}0.035^{* * *} \\
(0.005)\end{array}$ & $\begin{array}{l}0.025^{* * *} \\
(0.005)\end{array}$ & $\begin{array}{c}0.250 \\
(0.299)\end{array}$ \\
\hline Potential Experience (years) & $\begin{array}{l}0.019 * * * \\
(0.003)\end{array}$ & $\begin{array}{l}0.022^{* * *} \\
(0.003)\end{array}$ & $\begin{array}{l}0.020^{* * *} \\
(0.002)\end{array}$ & $\begin{array}{l}0.025^{* * *} \\
(0.003)\end{array}$ & $\begin{array}{c}0.278 \\
(0.300)\end{array}$ \\
\hline Potential Experience $^{2}$ & $\begin{array}{l}-0.042 * * * \\
(0.006)\end{array}$ & $\begin{array}{l}-0.050^{* * *} \\
(0.007)\end{array}$ & $\begin{array}{l}-0.046^{* * *} \\
(0.004)\end{array}$ & $\begin{array}{l}-0.051^{* * *} \\
(0.005)\end{array}$ & $\begin{array}{l}-0.094^{* * *} \\
(0.015)\end{array}$ \\
\hline Tenure (years) & $\begin{array}{c}0.001 \\
(0.002)\end{array}$ & $\begin{array}{c}0.004 * \\
(0.002)\end{array}$ & $\begin{array}{l}0.003^{* *} \\
(0.002)\end{array}$ & $\begin{array}{l}0.007 * * * \\
(0.001)\end{array}$ & $\begin{array}{c}0.001 \\
(0.002)\end{array}$ \\
\hline Log of Monthly Hours & $\begin{array}{l}0.233^{* * *} \\
(0.028)\end{array}$ & $\begin{array}{l}0.213 * * * \\
(0.033)\end{array}$ & $\begin{array}{l}0.212 * * * \\
(0.018)\end{array}$ & $\begin{array}{l}0.130^{* * *} \\
(0.020)\end{array}$ & $\begin{array}{l}0.079 * * * \\
(0.023)\end{array}$ \\
\hline \multicolumn{6}{|c|}{ Employee Owns (omitted: No Shares) } \\
\hline$<1 \%$ & $\begin{array}{l}0.146^{* * *} \\
(0.047)\end{array}$ & $\begin{array}{l}0.175^{* * *} \\
(0.047)\end{array}$ & $\begin{array}{l}0.084^{* * *} \\
(0.022)\end{array}$ & $\begin{array}{l}0.114^{* * *} \\
(0.022)\end{array}$ & $\begin{array}{l}0.073^{* * *} \\
(0.027)\end{array}$ \\
\hline$\geq 1 \%$ & $\begin{array}{l}0.211^{* * *} \\
(0.047)\end{array}$ & $\begin{array}{l}0.244^{* * *} \\
(0.054)\end{array}$ & $\begin{array}{l}0.226^{* * *} \\
(0.042)\end{array}$ & $\begin{array}{l}0.108^{* * *} \\
(0.037)\end{array}$ & $\begin{array}{c}0.071^{*} \\
(0.041)\end{array}$ \\
\hline No information & $\begin{array}{c}0.092^{*} \\
(0.050)\end{array}$ & $\begin{array}{l}0.133^{* *} \\
(0.064)\end{array}$ & $\begin{array}{c}0.068^{*} \\
(0.035)\end{array}$ & $\begin{array}{c}0.041 \\
(0.029)\end{array}$ & $\begin{array}{c}0.014 \\
(0.035)\end{array}$ \\
\hline Year 1995 & $\begin{array}{l}-0.045^{*} \\
(0.023)\end{array}$ & $\begin{array}{l}-0.041^{*} \\
(0.024)\end{array}$ & $\begin{array}{l}-0.054^{* * *} \\
(0.020)\end{array}$ & $\begin{array}{l}-0.073 * * * \\
(0.020)\end{array}$ & $\begin{array}{l}-0.301 \\
(0.300)\end{array}$ \\
\hline Year 1996 & $\begin{array}{l}0.095^{* * *} \\
(0.032)\end{array}$ & $\begin{array}{l}0.201 * * * \\
(0.049)\end{array}$ & $\begin{array}{l}0.091^{* *} \\
(0.044)\end{array}$ & $\begin{array}{l}0.058^{* *} \\
(0.024)\end{array}$ & $\begin{array}{l}-0.380 \\
(0.599)\end{array}$ \\
\hline Year 1998 & $\begin{array}{l}-0.249 * * * \\
(0.029)\end{array}$ & $\begin{array}{l}-0.008 \\
(0.087)\end{array}$ & $\begin{array}{l}-0.268^{* * * *} \\
(0.071)\end{array}$ & $\begin{array}{l}-0.276^{* * *} \\
(0.033)\end{array}$ & $\begin{array}{l}-1.176 \\
(1.197)\end{array}$ \\
\hline Year 2000 & $\begin{array}{l}-0.220 * * * \\
(0.042)\end{array}$ & $\begin{array}{l}-0.191 * * * \\
(0.050)\end{array}$ & $\begin{array}{l}-0.180 * * * \\
(0.041)\end{array}$ & $\begin{array}{l}-0.214^{* * *} \\
(0.022)\end{array}$ & $\begin{array}{l}-1.578 \\
(1.796)\end{array}$ \\
\hline Intercept & $\begin{array}{l}5.269 * * * \\
(0.179)\end{array}$ & $\begin{array}{l}5.366^{* * *} \\
(0.204)\end{array}$ & $\begin{array}{l}5.597 * * * \\
(0.103)\end{array}$ & $\begin{array}{l}6.101^{* * *} \\
(0.147)\end{array}$ & $\begin{array}{l}-0.676 \\
(9.121)\end{array}$ \\
\hline $\mathrm{R}^{2}$ overall & 0.323 & 0.128 & 0.458 & 0.271 & 0.005 \\
\hline
\end{tabular}

Notes: $\mathrm{N}=11363$ employee-respondents in the non-public sector. Dependent variable is log of real monthly contractual wage at the primary job. Robust standard errors are in parentheses; ${ }^{*}$-significant at $10 \%$; ${ }^{*}$-significant at $5 \%$; ${ }^{* * *}$-significant at $1 \%$. Standard errors in columns 1 through 3 are adjusted for clustering of districts. The excluded instrument is $\Omega_{\mathrm{t}}$ (local arrears). 9 occupation dummies, 9 industry dummies, and 2 dummies for missing values of wages and family income are included but not shown here. First-stage results are not reported but they are similar to Table 4. 
Table 8: Testing Model Assumptions -

Linear Reaction Function, Public Sector

\begin{tabular}{|c|c|c|c|c|}
\hline 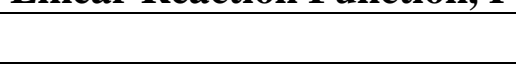 & OLS & District FE & Firm FE & Worker FE \\
\hline \multicolumn{5}{|l|}{ Panel A } \\
\hline \multirow[t]{2}{*}{$\Omega_{\mathrm{t}}$ (local arrears) } & $0.404 * * *$ & $0.298 * * *$ & $0.404 * * *$ & $0.469 * * *$ \\
\hline & $(0.061)$ & $(0.076)$ & $(0.054)$ & $(0.057)$ \\
\hline \multirow[t]{2}{*}{ Male } & 0.080 & 0.071 & 0.008 & $\ldots$ \\
\hline & $(0.081)$ & $(0.081)$ & $(0.134)$ & \\
\hline \multirow[t]{2}{*}{ Schooling (years) } & 0.007 & 0.015 & -0.000 & -0.029 \\
\hline & $(0.017)$ & $(0.016)$ & $(0.025)$ & $(0.040)$ \\
\hline \multirow[t]{2}{*}{ Age (years) } & -0.006 & -0.006 & 0.002 & $\ldots$ \\
\hline & $(0.004)$ & $(0.004)$ & $(0.006)$ & \\
\hline \multirow[t]{2}{*}{ Tenure (years) } & $0.027 * * *$ & $0.027 * * *$ & $0.010 *$ & 0.006 \\
\hline & $(0.006)$ & $(0.006)$ & $(0.006)$ & $(0.008)$ \\
\hline \multirow[t]{2}{*}{ Hourly Wage Rate (rubles) } & $-0.006 * * *$ & $-0.006 * *$ & $-0.007 * * *$ & $-0.008 * * *$ \\
\hline & $(0.002)$ & $(0.002)$ & $(0.003)$ & $(0.003)$ \\
\hline \multirow[t]{2}{*}{ Family Income (thous.rubles) } & $-0.024^{*}$ & -0.017 & $-0.038 *$ & $-0.039 *$ \\
\hline & $(0.013)$ & $(0.014)$ & $(0.022)$ & $(0.024)$ \\
\hline \multirow[t]{2}{*}{ Year 1995} & 0.076 & 0.077 & 0.065 & 0.039 \\
\hline & $(0.053)$ & $(0.056)$ & $(0.097)$ & $(0.099)$ \\
\hline \multirow[t]{2}{*}{ Year 1996} & $0.678 * * *$ & $0.779 * * *$ & $0.707 * * *$ & $0.586 * * *$ \\
\hline & $(0.100)$ & $(0.106)$ & $(0.109)$ & $(0.113)$ \\
\hline \multirow[t]{2}{*}{ Year 1998} & $1.301 * * *$ & $1.508^{* * *}$ & $1.442 * * *$ & $1.269 * * *$ \\
\hline & $(0.185)$ & $(0.219)$ & $(0.147)$ & $(0.154)$ \\
\hline \multirow[t]{2}{*}{ Year 2000} & 0.125 & 0.111 & $0.216^{* *}$ & $0.269 * *$ \\
\hline & $(0.113)$ & $(0.116)$ & $(0.109)$ & $(0.116)$ \\
\hline \multirow[t]{2}{*}{ Intercept } & 0.224 & -0.005 & 0.289 & 0.925 \\
\hline & $(0.240)$ & $(0.220)$ & $(0.417)$ & $(0.579)$ \\
\hline $\mathrm{R}^{2}$ overall & 0.136 & 0.150 & 0.125 & 0.120 \\
\hline \multicolumn{5}{|l|}{ Panel B } \\
\hline \multirow{2}{*}{$\begin{array}{l}\Omega_{\mathrm{t}}^{\mathrm{n}} \text { (local arrears in the non- } \\
\text { public sector) }\end{array}$} & $0.305^{* * *}$ & $0.270 * * *$ & $0.286 * * *$ & $0.353 * * *$ \\
\hline & $(0.046)$ & $(0.085)$ & $(0.043)$ & $(0.047)$ \\
\hline $\mathrm{R}^{2}$ overall & 0.132 & 0.151 & 0.121 & 0.092 \\
\hline
\end{tabular}

Notes: N=7010 employee-respondents in the public sector. The budgetary sector consists of municipal utilities, public services such as health care, education, and government, and defense industries. Robust standard errors are in parentheses; *significant at 10\%; **-significant at 5\%; ***-significant at 1\%. Standard errors in columns 1 and 2 are adjusted for clustering of districts. The public sector has neither industry categories nor employee ownership. 9 occupation dummies and 2 dummies for missing values of wages and family income are included but not shown here. 
Table 9: Non-Linear Reaction Function of Wage Arrears, Non-Public Sector

\begin{tabular}{lcccc}
\hline & OLS & District FE & Firm FE & Worker FE \\
\hline$\Omega$ (local arrears) & -0.249 & $-0.896^{* *}$ & -0.130 & 0.043 \\
& $(0.402)$ & $(0.423)$ & $(0.179)$ & $(0.160)$ \\
$\Omega^{2}$ & $0.304^{* *}$ & $0.333^{* * *}$ & $0.240^{* * *}$ & $0.173^{* * *}$ \\
& $(0.122)$ & $(0.116)$ & $(0.037)$ & $(0.034)$ \\
$\Omega^{3}$ & $-0.019 * *$ & $-0.020^{* * *}$ & $-0.014^{* * *}$ & $-0.010^{* * *}$ \\
& $(0.008)$ & $(0.007)$ & $(0.002)$ & $(0.002)$ \\
\hline $\mathrm{R}^{2}$ & 0.250 & 0.267 & 0.150 & 0.235 \\
\hline
\end{tabular}

Notes: $\mathrm{N}=12306$ employee-respondents in the non-public sector. Robust standard errors in parentheses; *-significant at $10 \%$; **_significant at 5\%; ${ }^{* * *}$-significant at $1 \%$. Standard errors in columns 1 and 2 are adjusted for clustering on district. The equations in this table also include all the other variables in Table 4, but the results for these variables are very similar and therefore not shown here.

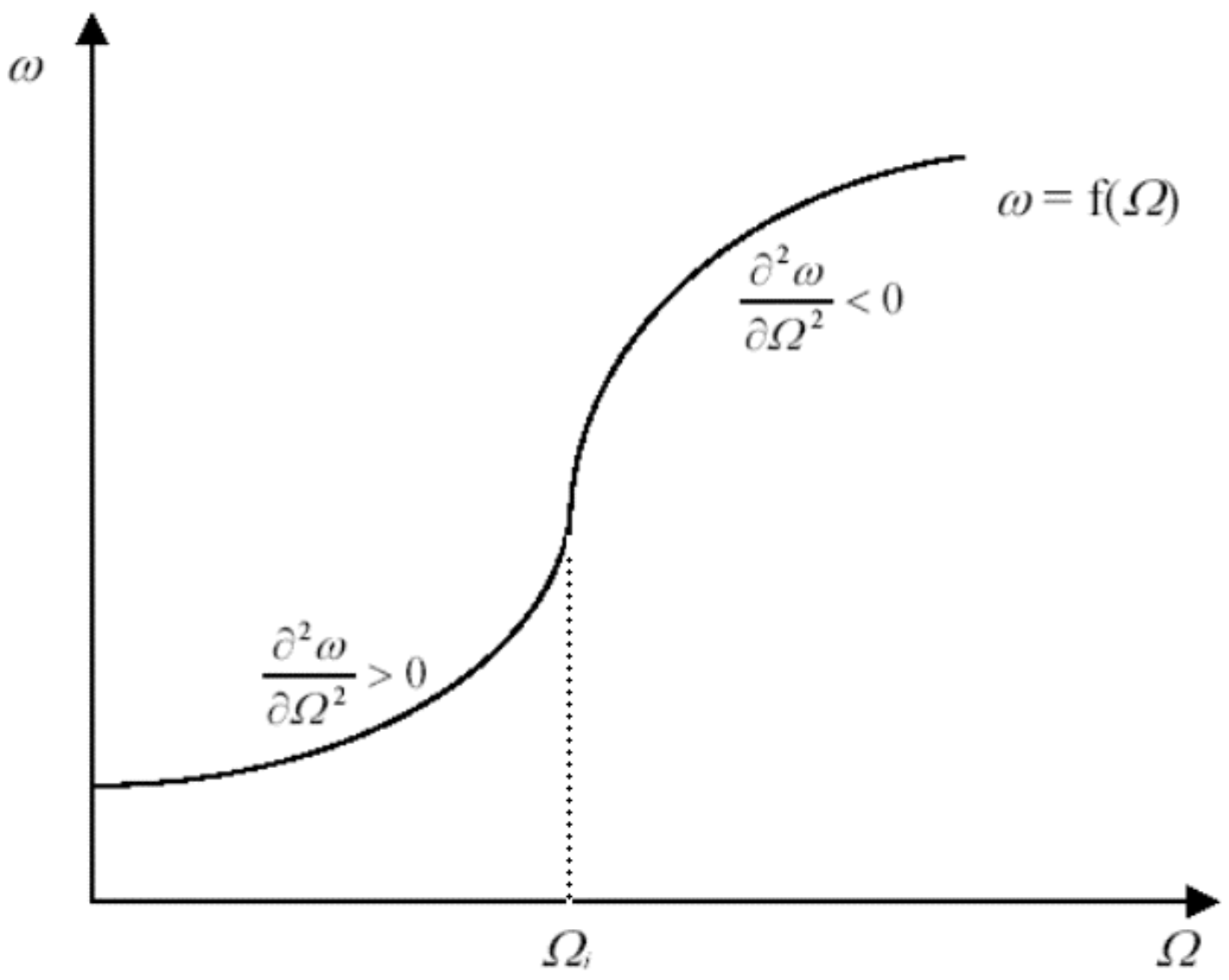

Figure 1: Non-Linear Reaction Function of Wage Arrears 


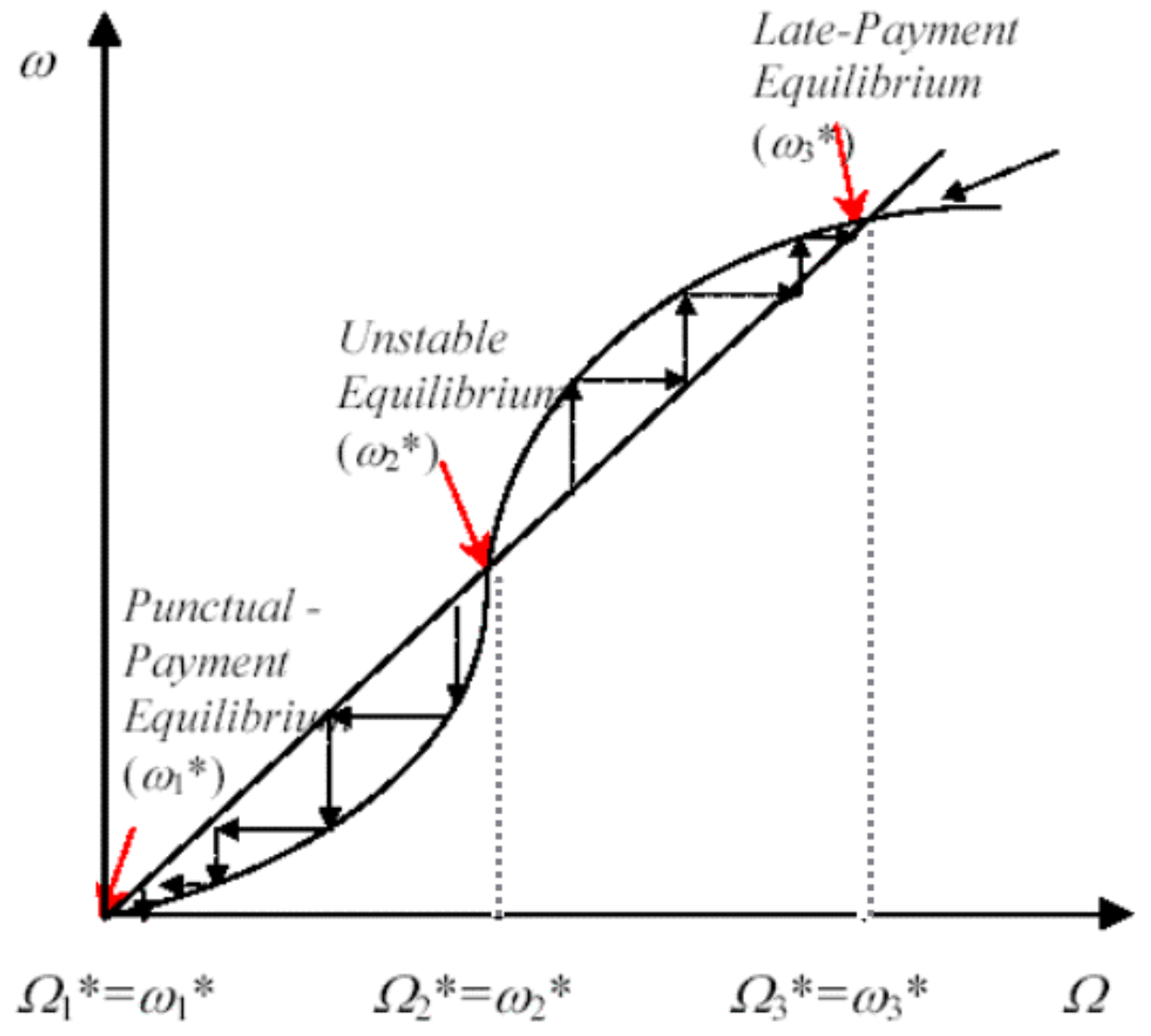

Figure 2: Symmetric Nash Equilibria 


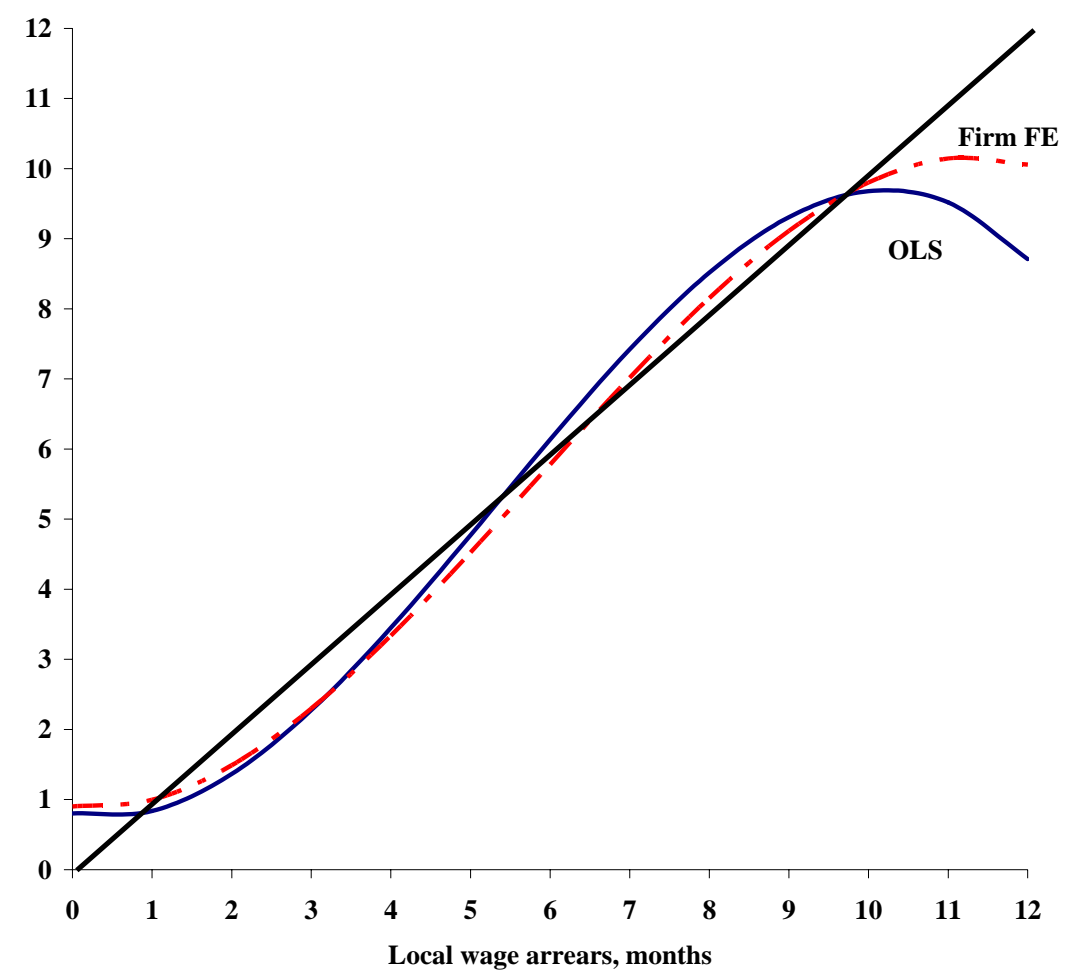

Figure 3: Estimated Nonlinear Reaction Function 


\section{DAVIDSON INSTITUTE WORKING PAPER SERIES - Most Recent Papers}

The entire Working Paper Series may be downloaded free of charge at: www.wdi.bus.umich.edu

CURRENT AS OF 7/06/04

\begin{tabular}{|c|c|c|}
\hline Publication & Authors & Date \\
\hline $\begin{array}{l}\text { No. 708: Contract Violations, Neighborhood Effects, and Wage Arrears } \\
\text { in Russia }\end{array}$ & $\begin{array}{l}\text { John S. Earle and Klara } \\
\text { Sabirianova Peter }\end{array}$ & July 2004 \\
\hline $\begin{array}{l}\text { No. 707: Determinants of Employment Growth at MNEs: Evidence } \\
\text { from Egypt, India, South Africa and Vietnam }\end{array}$ & $\begin{array}{l}\text { Sumon Kumar Bhaumik, Saul } \\
\text { Estrin and Klaus Meyer }\end{array}$ & July 2004 \\
\hline $\begin{array}{l}\text { No. 706: Economic Reform in Tanzania and Vietnam: A Comparative } \\
\text { Commentary }\end{array}$ & $\begin{array}{l}\text { Brian Van Arkadie and Do Duc } \\
\text { Dinh }\end{array}$ & June 2004 \\
\hline $\begin{array}{l}\text { No. 705: Beliefs about Exchange-Rate Stability: Survey Evidence } \\
\text { from the Currency Board in Bulgaria }\end{array}$ & $\begin{array}{l}\text { Neven T. Valev and John A. } \\
\text { Carlson }\end{array}$ & June 2004 \\
\hline No. 704: Returns to Schooling in China Under Planning and Reform & $\begin{array}{l}\text { Belton M. Fleisher and Xiaojun } \\
\text { Wang }\end{array}$ & June 2004 \\
\hline $\begin{array}{l}\text { No. 703: Return to Skills and the Speed of Reforms: Evidence from } \\
\text { Central and Eastern Europe, China and Russia }\end{array}$ & $\begin{array}{l}\text { Belton M. Fleisher, Klara } \\
\text { Sabirianova Peter, and Xiaojun } \\
\text { Wang }\end{array}$ & June 2004 \\
\hline $\begin{array}{l}\text { No. 702: What Makes Small Firms Grow? Finance, Human Capital, } \\
\text { Technical Assistance, and the Business Environment in Romania }\end{array}$ & $\begin{array}{l}\text { J. David Brown, John S. Earle } \\
\text { and Dana Lup }\end{array}$ & May 2004 \\
\hline $\begin{array}{l}\text { No. 701: The Effects of Multiple Minimum Wages Throughout the } \\
\text { Labor Market }\end{array}$ & $\begin{array}{l}\text { T. H. Gindling and Katherine } \\
\text { Terrell }\end{array}$ & May 2004 \\
\hline No. 700: Minimum Wages, Inequality and Globalization & $\begin{array}{l}\text { T. H. Gindling and Katherine } \\
\text { Terrell }\end{array}$ & May 2004 \\
\hline No. 699: Self-Selection and Earnings During Volatile Transition & Ralitza Dimova and Ira Gang & May 2004 \\
\hline No. 698: Ecology and Violence: The Environmental Dimensions of War & $\begin{array}{l}\text { Timothy L. Fort and Cindy A. } \\
\text { Schipani }\end{array}$ & May 2004 \\
\hline $\begin{array}{l}\text { No. 697: Russian Cities in Transition: The Impact of Market Forces in } \\
\text { the 1990s }\end{array}$ & Ira N. Gang and Robert C. Stuart & May 2004 \\
\hline $\begin{array}{l}\text { No. 696: Firm Ownership and Internal Labor Practices in a Transition } \\
\text { Economy: An Exploration of Worker Skill Acquisition in Vietnam }\end{array}$ & Jed Friedman & May 2004 \\
\hline No. 695: The Unanticipated Effects of Insider Trading Regulation & $\begin{array}{l}\text { Art A. Durnev and Amrita S. } \\
\text { Nain }\end{array}$ & May 2004 \\
\hline $\begin{array}{l}\text { No. 694: Volatile Interest Rates, Volatile Crime Rates: A New } \\
\text { Argument for Interest Rate Smoothing }\end{array}$ & Garett Jones and Ali M. Kutan & May 2004 \\
\hline $\begin{array}{l}\text { No. } 693 \text { Money Market Liquidity under Currency Board - Empirical } \\
\text { Investigations for Bulgaria }\end{array}$ & $\begin{array}{l}\text { Petar Chobanov and Nikolay } \\
\text { Nenovsky }\end{array}$ & May 2004 \\
\hline $\begin{array}{l}\text { No. 692: Credibility and Adjustment: Gold Standards Versus Currency } \\
\text { Boards }\end{array}$ & $\begin{array}{l}\text { Jean Baptiste Desquilbet and } \\
\text { Nikolay Nenovsky }\end{array}$ & May 2004 \\
\hline $\begin{array}{l}\text { No. 691: Impact of Cross-listing on Local Stock Returns: Case of } \\
\text { Russian ADRs }\end{array}$ & Elena Smirnova & May 2004 \\
\hline $\begin{array}{l}\text { No. 690: Executive Compensation, Firm Performance, and State } \\
\text { Ownership in China:Evidence from New Panel Data }\end{array}$ & Takao Kato and Cheryl Long & May 2004 \\
\hline $\begin{array}{l}\text { No. 689: Diverging Paths: Transition in the Presence of the Informal } \\
\text { Sector }\end{array}$ & Maxim Bouev & May 2004 \\
\hline $\begin{array}{l}\text { No. 688: What Causes Bank Asset Substitution in Kazakhstan? } \\
\text { Explaining Dollarization in a Transition Economy }\end{array}$ & Sharon Eicher & May 2004 \\
\hline $\begin{array}{l}\text { No. 687: Financial Sector Returns and Creditor Moral Hazard: Evidence } \\
\text { from Indonesia, Korea and Thailand }\end{array}$ & $\begin{array}{l}\text { Ayse Y. Evrensel and Ali M. } \\
\text { Kutan }\end{array}$ & May 2004 \\
\hline $\begin{array}{l}\text { No. 686: Instability in Exchange Rates of the World Leading } \\
\text { Currencies: Implications of a Spatial Competition Model }\end{array}$ & $\begin{array}{l}\text { Dirk Engelmann, Jan Hanousek } \\
\text { and Evzen Kocenda }\end{array}$ & May 2004 \\
\hline $\begin{array}{l}\text { No. 685: Spinoffs, Privatization, and Corporate Performance in } \\
\text { Emerging Markets }\end{array}$ & $\begin{array}{l}\text { Jan Svejnar, Evzen Kocenda and } \\
\text { Jan Hanousekf }\end{array}$ & May 2004 \\
\hline $\begin{array}{l}\text { No. 684: CPI Bias and Real Living Standards in Russia During the } \\
\text { Transition }\end{array}$ & $\begin{array}{l}\text { John Gibson, Steven Stillman and } \\
\text { Trinh Le }\end{array}$ & May 2004 \\
\hline $\begin{array}{l}\text { No. 683: Mission Implausible III: Measuring the Informal Sector in a } \\
\text { Transition Economy using Macro Methods }\end{array}$ & Jan Hanousek and Filip Palda & May 2004 \\
\hline
\end{tabular}

